\title{
Southern Central Andes Neogene magmatism over the Pampean Flat Slab: implications on crustal and slab melts contribution to magma generation in Precordillera, Western Argentina
}

\author{
*Stella Poma ${ }^{1,2}$, Adriana Ramos², Vanesa D. Litvak ${ }^{1,3}$, \\ Sonia Quenardelle ${ }^{1,2}$, Emma B. Maisonnave ${ }^{1,2}$, Iris Díaz \\ I Universidad de Buenos Aires, Facultad de Ciencias Exactas y Naturales, Departamento de Ciencias Geológicas, Pabellón II, Ciudad \\ Universitaria, Intendente Guiraldes 2160, C1428 EGA, Núñez, Buenos Aires, Argentina. \\ stella.poma@gmail.com; vane@gl.fcen.uba.ar;sonia@gl.fcen.uba.ar; beatriz@gl.fcen.uba.ar \\ 2 CONICET-Universidad de Buenos Aires, Instituto de Geociencias Básicas y Aplicadas de Buenos Aires (IGEBA), Pabellón II, Ciudad \\ Universitaria, Intendente Guiraldes 2160, C1428 EGA, Núñez, Buenos Aires, Argentina. \\ amramos@gl.fcen.uba.ar \\ 3 CONICET-Universidad de Buenos Aires, Instituto de Estudios Andinos Don Pablo Groeber (IDEAN), Pabellón II, Ciudad Universitaria, \\ Intendente Guiraldes 2160, C1428 EGA, Núñez, Buenos Aires, Argentina. \\ 4 Servicio Geológico Minero Argentino (SEGEMAR), Delegación San Juan, Sargento Cabral 685 (Oeste), (5400) San Juan, Argentina. \\ idiaz.2009@hotmail.com \\ * Corresponding author: stella.poma@gmail.com
}

\begin{abstract}
A Miocene to Pliocene (13 to $4.6 \mathrm{Ma}$ ) mostly pyroclastic sequence is exposed along the Iglesia Valley, to the east of the former main volcanic arc. This area is a transitional region between Cordillera Frontal and Precordillera, over the flat slab segment of the Southern Central Andes, at 29 $30^{\prime}$ S to $30^{\circ} 00^{\prime}$ S. New radiometric ages, geochemical data, petrography and field relationships are evaluated to establish differences and similarities between Miocene arcrelated sequences across the main arc and its expansion towards a back arc position, in western Precordillera. Analyzed rocks have a magmatic arc signature partially like the former main volcanic arc to the west. The Iglesia Valley rocks are LREE-enriched (La/Sm: 3.7-6.5) with respect to HREE ( $\mathrm{Sm} / \mathrm{Yb}: 2.2-6.0)$ and define patterns with a pronounced slope. $\mathrm{Sm} / \mathrm{Yb}$ ratios generally increase with time, as pressures increase, with retention of HREE in residual mineralogy, particularly garnet at $\mathrm{Sm} / \mathrm{Yb}>4$. Volcanic activity in Cordillera Frontal and the volcanic-volcaniclastic expression in Precordillera show a continuous increase in the $\mathrm{La} / \mathrm{Yb}$ ratio with decreasing age. Variations in the residual mineral phase equilibrating with magmas would be related to the progressive increase in crustal thickness due to the tectonic compressive regime resulting from shallow subduction since Middle Miocene. The data presented suggest that the arc magmatic activity during the Miocene was expanded notably to the East in relation to the location of the main arc at Valle del Cura, in Cordillera Frontal. The extensive amplitude of the volcanic arc activity is indicative of the slab gradual flattening. Particularly, the mantle-derived magmas from Lomas del Campanario Formation (Western Precordillera) are enriched by subduction related fluids but also by crustal components. It is interpreted that the cause of the geochemical differences between the back arc position rocks and the main arc lay in the heterogeneous composition of the underlying continental crust involved in both locations. Presence of volcanic rocks with adakitic geochemical affinity probably reflect astenospheric-derived melts that interacted through a heterogeneous and thickened crust toward the surface.
\end{abstract}




\begin{abstract}
RESUMEN. Magmatismo neógeno en la sección sur de los Andes centrales sobre la zona de subducción horizontal pampeana: implicancias respecto de las contribuciones de los fundidos corticales y de la placa subductada en la generación de magmas en precordillera, Argentina. Una secuencia de rocas volcánicas, predominantemente piroclástica de edad miocena superior a pliocena (13 a 4,6 Ma), está expuesta a lo largo del Valle de Iglesia, al este del arco volcánico principal de la cordillera de los Andes. Esta área está ubicada sobre el segmento de subducción subhorizontal Pampeano en los Andes centrales del sur, entre los $29^{\circ} 30^{\prime} \mathrm{S}$ y $30^{\circ} 00^{\prime} \mathrm{S}$ y separa la cordillera frontal de la precordillera. Nuevas edades radiométricas, datos geoquímicos, estudios petrográficos y relaciones de campo permiten establecer similitudes y diferencias entre la actividad magmática miocena del arco volcánico principal y su expansión hacia el este en el Valle de Iglesia, en la precordillera occidental. Las rocas analizadas tienen una impronta geoquímica de arco magmático similar a las del frente volcánico principal coetáneo, ubicado al oeste. Las rocas del Valle de Iglesia están enriquecidas en LREE ( $\mathrm{La} / \mathrm{Sm}: 3,7-6,5)$ con respecto a HREE ( $\mathrm{Sm} / \mathrm{Yb}: 2,2-6,0)$ y definen patrones normalizados con pendiente pronunciada. Las relaciones $\mathrm{Sm} / \mathrm{Yb}$ generalmente se incrementan con el tiempo, reflejo del aumento en las condiciones de presión, con retención de HREE en la mineralogía residual, particularmente a relaciones $\mathrm{Sm} / \mathrm{Yb}>4$. La actividad volcánica en la cordillera frontal y las secuencias volcánicas-volcanoclásticas de la precordillera muestran un continuo aumento de los valores de la razón $\mathrm{La} / \mathrm{Yb}$ con la disminución de la edad. Estas variaciones son compatibles con cambios en la mineralogía residual de los magmas que evidencian un incremento de la presión con el tiempo, con retención de HREE en la mineralogía residual, en particular de granate. Las variaciones en la mineralogía de la fase residual en la fuente estarían relacionadas con el progresivo aumento del espesor cortical, ocasionado por el régimen tectónico compresivo producto de la somerización de la placa oceánica subducida desde el Mioceno medio. Sobre la base de los contenidos de elementos incompatibles se puede inferir que gran parte de las rocas volcánicas del Valle de Iglesia tienen una afinidad adakítica. Los datos geoquímicos y geocronológicos presentados permiten identificar que la actividad magmática del arco durante el Mioceno se expandió notablemente hacia el este en relación con la ubicación del arco principal en Valle del Cura, en la cordillera frontal. La extensa amplitud del frente orogénico es en sí misma otra indicación de la gradual subhorizontalización de la placa subducida. En particular, los magmas derivados del manto y que dieron origen a las rocas volcánicas de la Unidad Lomas del Campanario en el Valle de Iglesia, fueron modificados por fluidos aportados por la placa subducida, pero también por componentes corticales. Las diferencias geoquímicas observadas entre las rocas volcánicas del Valle de Iglesia y sus equivalentes del arco volcánico principal pueden ser explicadas por la composición heterogénea de la corteza continental subyacente involucrada en ambas localizaciones. Las rocas volcánicas identificadas con afinidad geoquímica adakítica probablemente reflejen fundidos derivados de la cuña astenosférica que interactuaron con una corteza heterogénea y engrosada, durante su ascenso a superficie.
\end{abstract}

Palabras clave: Magmatismo mioceno, Geoquímica, Edades radiométricas, Expansión del arco, Subducción somera.

\section{Introduction}

A Miocene to Pliocene pyroclastic sequence with related lava flows and subvolcanic rocks is exposed along the Iglesia Valley Basin and surrounding areas, between Western Precordillera and Cordillera Frontal, in San Juan Province. This volcanic activity was coeval with the main volcanic arc developed at these latitudes, over the present-day Pampean flat-slab region of Southern Central Andes. The geodynamic evolution of the Paleogene to Neogene main volcanic arc has been studied in the last years on the basis of chemical, petrographic and radiometric ages relationships of the involved volcanic units (Kay et al., 1991, 1999; Kay and Mpodozis, 2002; Bissig et al., 2001, 2003; Litvak et al., 2007; Litvak and Poma, 2005, 2010, 2014; Jones et al., 2016); however, magmatic activity developed at the same latitudes but in a back arc position is less known. These deposits include a sedimentary and pyroclastic rock sequence known as Lomas del Campanario Formation (Wetten, 1975, 2005; Contreras et al., 1990) and lava flows related to shallow intrusives, named Miocene Intrusives and Tertiary Intrusives (Cardó and Díaz, 1999; Cardó et al., 2007; Llambías et al., 1990). Lomas del Campanario Formation, together with the sedimentary Las Flores Formation, constitutes the Iglesia Group (Wetten, 1975).

New radiometric ages, geochemical data, petrography and field relationships of the volcanic and pyroclastic sequences are analyzed with the aim to evaluate differences and similarities between the main arc volcanism and its expansion towards a back arc position during a time-span from $\sim 18$ to $\sim 4 \mathrm{Ma}$. For that purpose, we use in this work the denomination Lomas del Campanario Formation to refer to all the lava flows, subvolcanic intrusives and pyroclastic facies that constitute the eastern expression of the arc-related volcanic sequences during EarlyMid Miocene to early Pliocene times (18-5 Ma) 
developed in the Iglesia Valley Basin. The main question is which was the role and composition of the crust that might contaminate primitive magmas during their ascent towards the surface. To do that, we compare Lomas del Campanario Formation with two sets of rocks: one representative of the main arc magmatism at the same latitude and the other one, the back arc rocks at southern Puna latitude. The volcanic sequences selected with this purpose are those contemporaneous to the ones cropping out at Valle del Cura area in Cordillera Frontal, San Juan, Province: Cerro de las Tórtolas, Tambo Formations and Vacas Heladas Ignimbrite (Kay et al., 1991; Bissig et al., 2001; Litvak et al., 2007; Jones et al., 2016) and Cerro Blanco in Puna Austral (Montero López et al., 2010).

\section{Tectonic Setting}

The study area is located within the PampeanChilean flat slab segment of the Southern Central
Andes $\left(27^{\circ} \mathrm{S}-33^{\circ} \mathrm{S}\right)$ characterized, at present, by the lack of active volcanism (Fig.1). At these latitudes, Miocene volcanism was intensively developed in the volcanic arc front, which was located in Valle del Cura area near the present Argentine-Chilean border; however, coetaneous magmatism with arc features was also developed towards the foreland, into the Iglesia Valley.

The Iglesia Valley (Fig. 2) is part of the so-called Iglesia-Calingasta-Uspallata depression, which is a mostly NS intermountain structure that stretches from $29^{\circ} 30^{\prime} \mathrm{S}$ to $32^{\circ} 30^{\prime} \mathrm{S}$, along $350 \mathrm{~km}$ (Ramos et al., 1984). It is bounded by the Cordillera del Colangüil (Cordillera Frontal, San Juan Province) to the west and by the Western Precordillera to the east. Beer et $a l$. (1990) established that its fill reaches up to $3.5 \mathrm{~km}$ in depth, with thinning toward the edges. The long linear Iglesia-Calingasta-Uspallata depression has a significative tectonic importance since the Paleozoic, when the collision between Chilenia and the Western proto-Gondwana terranes took place

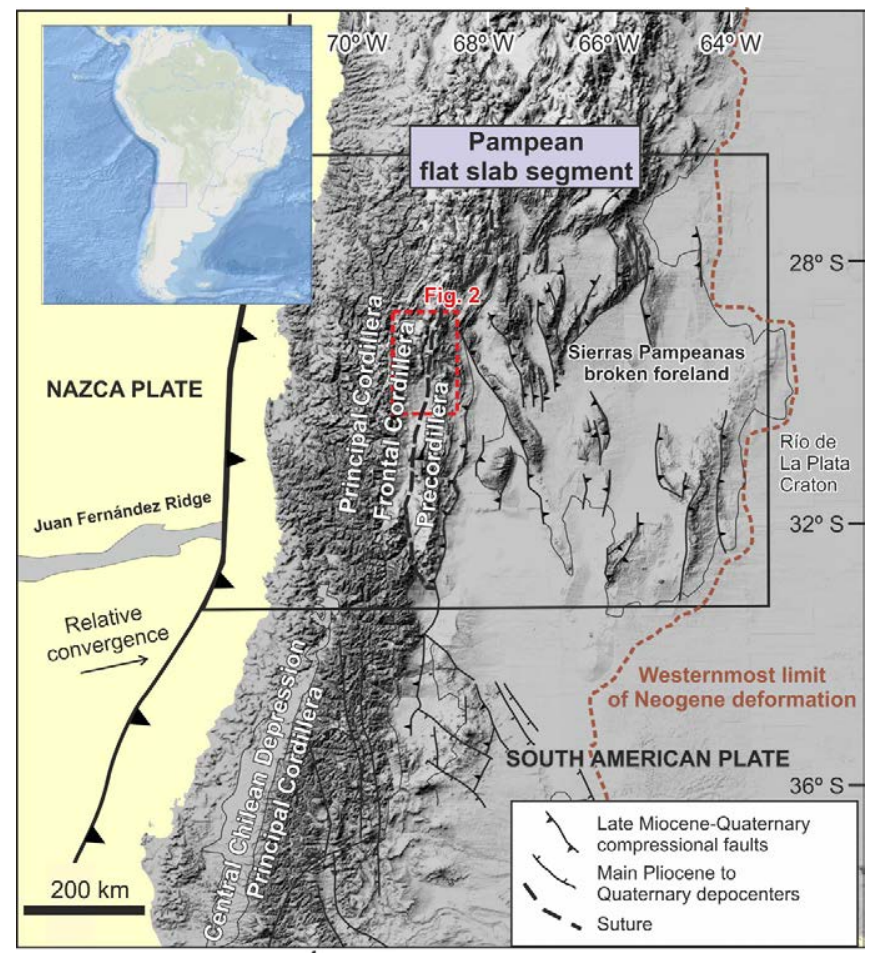

FIG. 1. Tectonic framework of the Southern Central Andes and main morphotectonic features of the present-day Pampean flat-slab subduction segment. A compressive regime associated with flat-slab segment is responsible for the uplifting of the Sierras Pampeanas (modified from Litvak et al., 2015). Precordillera and Cordillera Frontal suture is based on Ramos (1988). Dashed square indicates mapped area of figure 2 . 


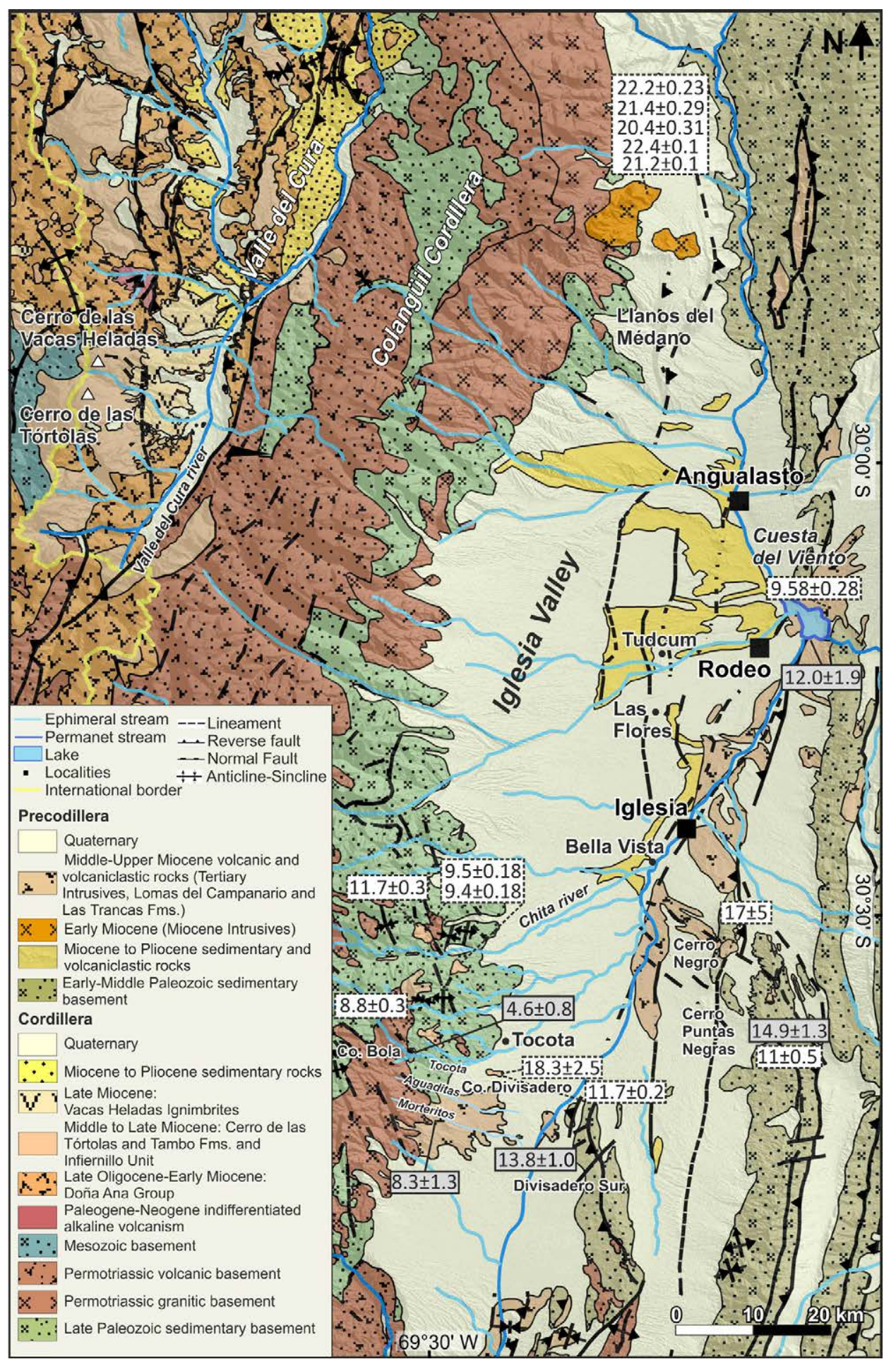

FIG. 2. Geology and distribution of arc-related sequences between $29^{\circ}$ to $31^{\circ} \mathrm{S}$ across the Frontal Cordillera and Precordillera, from the Valle del Cura area to the Iglesia Valley, over the present-day Pampean flat-slab segment (based on Cardó and Díaz, 1999; Cardó et al., 2007; Litvak et al., 2007; Gómez-Rivarola, 2007; Alonso et al., 2011; Litvak and Poma, 2014). Dashes rectangles correspond to published ages (Table 1). Filled-line squares correspond to new ages from this work (Table 2). 
(Ramos et al., 1984, 2004). At present, it includes the suture between both terranes and separates the Precordillera and Cordillera Frontal (Fig.1) (Ramos et al., 1984, 2004).

During Miocene times, the basin was passively transported above a horizontal décollement surface that links mid-crustal deformation, beneath the Cordillera Frontal, with surface thrusting in the western Precordillera (Jordan et al., 1993a). Deformation and structural style are compatible with the simultaneous uplift of the Cordillera Frontal and the Precordillera. Besides, prior to the Cordillera del Colangüil rise, the Iglesia Valley Basin was connected with the Valle del Cura area and it was only since the Late Miocene (Alonso et al., 2011) that the Colangüil rising began to separate both depocenters. Previously, during Early to Middle Miocene, Andean compression formed the La Tranca thrust separating the eastern Iglesia Valley Basin from the western Bermejo foreland Basin (Jordan et al., 1993a, b). The rise of La Tranca thrust in Precordillera was temporally correlated with extensive eruptions of the calc-alkaline andesitic lava flows in the Valle del Cura region. Indeed, the regional structure is a result of the increase of the compressional regimen by Middle Miocene due to the slab shallowing that has been attributed to the collision of the Juan Fernández Ridge with the South American plate (Pilger, 1981, 1984; Yáñez et al., 2001; Kay and Mpodozis, 2002). Thus, the increase in compressional setting due to shallow subduction influenced the genesis and evolution of Middle to Late Miocene (13-6 Ma) volcanic rocks in the main arc as reflected in their geochemical signature (Ramos et al., 1987, 1989; Kay and Abruzzi, 1996; Kay and Mpodozis, 2002; Kay et al., 1991, 1999; Litvak et al., 2007; Jones et al., 2016).

\section{Distribution and petrography of Western Precordillera magmatism}

\subsection{Pyroclastic Rocks}

The Iglesia Valley infill records the accumulation of an important sedimentary sequence with interbedded volcaniclastic rocks, also associated with intermediate lavas and intrusives (Fig. 2). In the first geological map of San Juan province (Minera TEA, 1968 in Ramos et al., 1989), the pyroclastic deposits were identified as "Formation of Tuffs, Breccias and Agglomerates". Later, they were defined as Lomas del Campanario Formation, a part of the Iglesia Group of Lower to Upper Miocene age (Wetten, 1975; Aparicio, 1984; Weidmann et al., 1985; Contreras et al., 1990; Bercowski, 1993; Díaz, 2011). According to Wetten (1975), Lomas del Campanario Formation is composed by a sedimentary upper section and a lower section characterized by andesitic to dacitic volcanic breccias, tuffs and volcanic bombs, with minor interbedded sedimentary deposits. Particularly, the latter were included as Las Flores Formation (Cardó and Díaz, 1999). Similar rocks were described by Alonso et al. (2011) in the Cuesta del Viento area to the north (Fig. 2). The pyroclastic deposits, together with the volcanic to subvolcanic rocks, are grouped in this work as Lomas del Campanario Formation.

Explosive volcanism has generated a well-preserved sequence of pyroclastic flows with surge and ash fall deposits, which are exposed along the Iglesia Valley as extensive series of low relief deposits (Fig. 3A). Related to this volcanic event, scarce andesitic to dacitic lava flows are present in the region, together with small and subordinate mesosilicic and basic subvolcanic intrusives hosted in Paleozoic rocks, named Tertiary Intrusives and Miocene Intrusives (Llambías et al., 1990; Cardó and Díaz, 1999; Cardó et al., 2007). There is no morphological indication that allows identifying the original vents for these deposits; however, main characteristics of the pyroclastic rocks are clearly shown when fluvial erosion cuts through volcanic sequence, which allow reconstructing its stratigraphy. Locally, the pyroclastic accumulations are truncated by younger, mostly fluvial epiclastic deposits. To the north, in Cuesta del Viento area, major accumulations of pyroclastic flows interbedded with surges and ash fall deposit are preserved.

Occasionally, deformation of the juvenile pumice fragments presents in the pyroclastic rocks from Cuesta del Viento is diagnostic of the high temperature conditions that prevailed during the flows (Fig. 3C). Similar rocks are known in exposures located between Iglesia and Las Flores areas and along the Iglesia river Valley where a succession of interlayered surges and pyroclastic flow deposits are exposed and well preserved (Fig. 2).

Three major units of pyroclastic flows can be regionally mapped according to their distribution and thickness. They are distributed in the southern part of Iglesia Valley and along the eastern piedmont slope of the Cordillera Frontal, on top of the metasedimentary and crystalline Ordovician basement rocks (Fig. 2). 

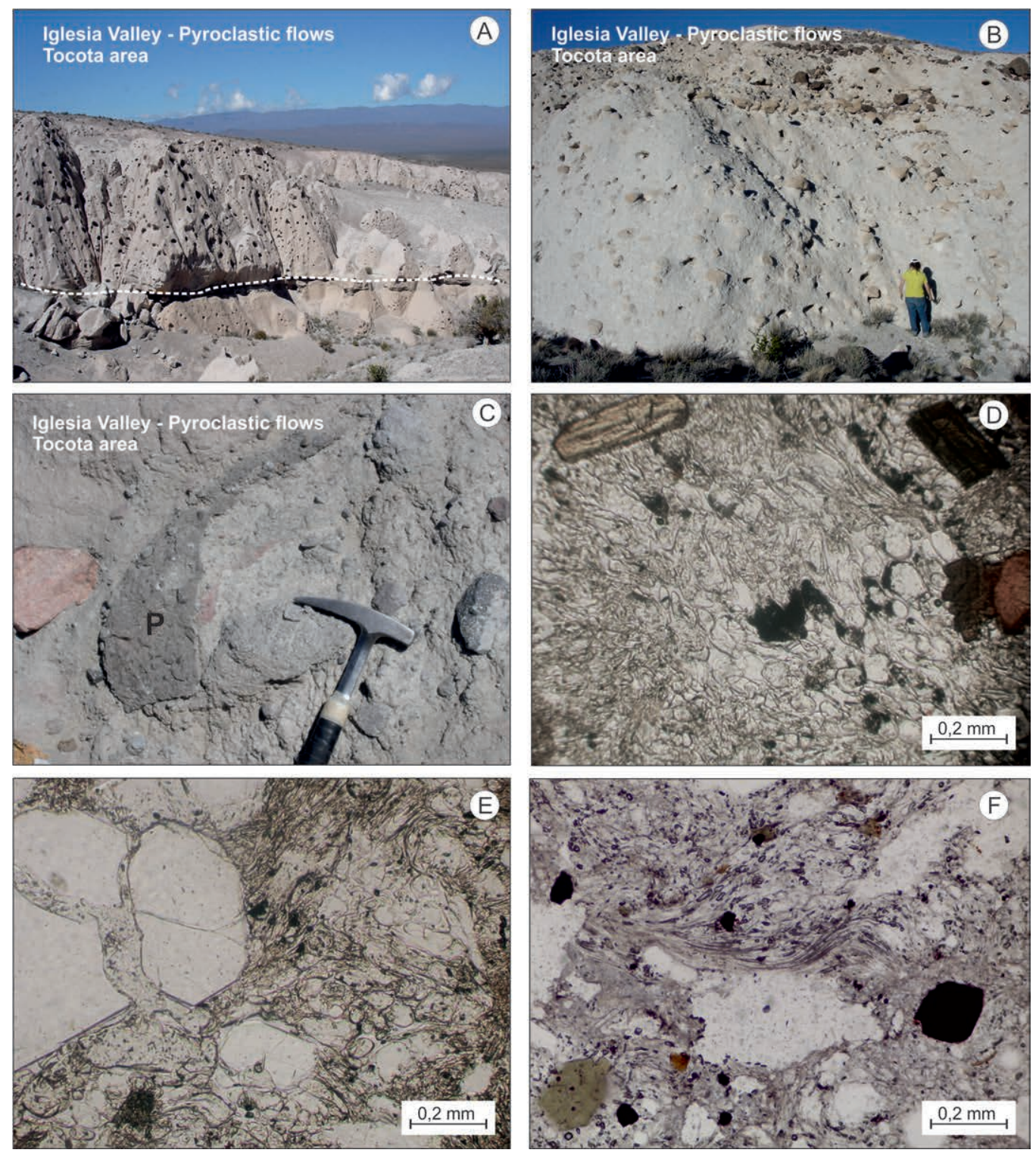

FIG. 3. Pyroclastic rocks of the Lomas del Campario Formation. A. Pyroclastic flow in Tocota area at Iglesia Valley showing two flow units; B. Detailed on the top of one pyroclastic flow, with reversely graded coarse pumice fragments; C. Deformation of a pumice fragment $(\mathrm{P})$ transported under plastic conditions at high temperature; D. Vitreous to crystalline tuff of the pyroclastic deposits at Iglesia Valley, with well preserved bubbles, and amphibole and biotite as main mafic phases; E. Crystalline to vitreous tuff with quartz and preserved bubbles and shards; F. Similar vitreous to crystalline tuffs with a more welded texture, with fluidal aspect in the matrix.

The pyroclastic lower units, located near the basin border, have around $10 \mathrm{~m}$ of thickness and lies over red sedimentary rocks. It is a massive pyroclastic flow made up by ash, K-feldspar crystal fragments, quartz and biotite. This lower unit has abundant pumice fragments up to $3 \mathrm{~cm}$ in diameter and scarce smaller lithic fragments. Both types of fragments show normal grading. On top of this deposit lays a second pyroclastic flow unit. It is thicker and it has a more important areal distribution. It extends laterally covering previous flow, without any erosive surface, and also covers Carboniferous sediments 
and Ordovician basement rocks. The thickness of the deposits is variable as the geometry wedges laterally. Throughout the basin, they have been measured from a few meters to about $800 \mathrm{~m}$ in the thickest areas (Ré and Barredo, 1993).

Southward of Tocota creek (Fig. 2), further pyroclastic deposits can be seen across the whitish hills that are leaned against the eastern most Cordillera Frontal elevations. They are massive deposits with a thin basal layer $(3 \mathrm{~cm})$ characterized by lapilli concentration, which continues upward with a matrix supported massive flow, mostly made up of ash and quartz, K-feldspars, hornblende and biotite crystal fragments. The deposit contains subordinated pumice fragments of up to $5 \mathrm{~cm}$ in longitude which are displayed with inverse grading and very few lithic fragments $(<5 \%)$. On the top, a coarse grained pyroclastic deposit is recognized; it is characterized by ash and crystal fragments with abundant and inversely graded pumice. The amount of pumice fragments increases from bottom to the top of this flow unit (Fig. 3A and B). At the base, it is matrix supported while at the top is clast supported. The principal fraction of the clasts has rounded to sub rounded shapes acquired along transport. Fragments with plastic deformation because of the combined effect of transportation and high temperature stress are scarce (Fig. 3C). The inverse grading of the pumice fragments as well as the notable increase in frequency and size towards the higher levels of the flow indicate high density contrast between vitroclasts and matrix.

At Cerro de La Cruz and surrounding areas $\left(30^{\circ} 22^{\prime} 30^{\prime \prime} \mathrm{S}-69^{\circ} 12^{\prime} 25^{\prime \prime} \mathrm{W}\right.$; Fig. 2) distribution of size and sorting of the fragments in the deposits are heterogeneous, characteristic of blocks and ash type deposits. Blocks and fragments are of andesitic and dacitic composition, some with metric size lengths. The smaller fractions $(<2 \mathrm{~cm})$ are lithic fragments of metasedimentary rocks derived from the basement that corresponds to Yerba Loca Formation. The mineralogical composition of the crystal fragments is made up of plagioclase, amphibole, biotite, $\mathrm{K}$-feldspar and subordinate quartz. Plagioclase is the most abundant mineral and it is an early crystallized phase. Phenocrysts and fragments of crystals show both, normal and reverse zoning and some crystals display partial resorption that was modified by later overgrown, giving a patchy texture. Partially reabsorbed crystals sometimes with inclusions of glass or minerals are textural features that suggest open magmatic chambers processes or magma mixing ones.

Amphibole is the first mafic phase to crystallize in the magma represented by these pyroclastic rocks and, generally, it is the dominant mafic mineral (Fig. 3D). Frequently, the crystals show compositional zonation, with variation in color, from brown at the core to green in the edge. The amphibole crystals show the characteristic habits, but the borders are frayed, a few crystals are surrounded by opaque minerals reaction rims. Biotite is the second mafic phase, but it is not present in all rocks. Quartz is a common mineral phase, appears as crystal fragments of different size showing simultaneously sharp edges and embayments. As a minor magmatic phase, there are K-feldspar and magnetite, while apatite and zircon are accessory minerals. The matrix usually contains undeformed bubble-wall, small pumice fragments that show relict tube vesicle texture and glassy shards (Fig. 3D, E); though some varieties evidence more welded texture (Fig. 3F). Sometimes, the alignment of the pumices, parallel to the flow surface, gives a particular fluidal texture.

Textural evidences point out that the analyzed sequence corresponds to highly explosive facies. It is made up by a dominant proportion of ash, phenocrysts and crystal fragments produced by magma fragmentation. The deposit contains pumice fragments inversely graded, which increase their frequency (80\%) towards the top. Pumice fragments are highly vesicular, but are not deformed indicating that the transport and deposition did not occur at high temperature. The observed structures, mainly massive in sectors and with diffuse layering, allow inferring that the flow transport was laminar. The flows with low aspect ratio extended as a continuous layer covering previous relief (Walker et al., 1980).

\subsection{Lavas and subvolcanic intrusives}

Locally and contemporaneous with the pyroclastic deposits, mesosilicic to acidic lava flows and sills were emplaced in the area, associated to scarce basalt and basaltic andesite lava flows. However, earliest Miocene magmatic activity is exposed at the north of Iglesia Valley (Llanos del Médano, Fig. 2) as small and shallow emplaced gabbroic to granitic bodies known as Miocene Intrusives (22-20 Ma; Llambías et al., 1990; Jones et al., 2016). 
The focus of this study comprises the younger Miocene lavas and subvolcanic rocks from Western Precordillera ( $c a .18-5 \mathrm{Ma}$ ) that are mostly exposed in the central and southern part of the Iglesia Valley (Fig. 2), associated to the previously described pyroclastic facies. These rocks were alternatively grouped as Tertiary Intrusives, Andesita Cerro Bola and/or Grupo Olivares (Aparicio, 1984; Wetten, 2005; Cardó et al., 2007), although we include them within the Lomas del Campanario Formation, together with their coetaneous pyroclastic deposits.

These lavas and subvolcanic intrusives irregularly crop out along the Iglesia Valley, mainly at eastern Tocota region at Cerro Negro and Cerro Puntas Negras (Fig. 2). Lava flows and intrusives also extend to the west in the eastern slope of Cordillera del Colangüil: Quebrada de Chita, Quebrada de Tocota and Cerro Divisadero (Fig. 2). The lava flows and the subvolcanic rocks show hydrothermal and/or pneumatolytic overprinted process. This activity was responsible for the mineralization of economic interest present in Chita and Tocota area (Wetten, 1995; Cardó et al., 2007).

Outcrops constitute small, low and irregular hills with gentle slopes, generally oriented along NS direction (Fig. 4A, B). Lavas and shallow intrusives are andesites and dacites with hornblende and subordinated biotite (Fig. 4C). Some of these rocks have vesicular structure with small cavities, occasionally filled by siliceous material. Their mineralogy is dominantly constituted by plagioclase (oligoclase-andesine) and amphibole, with minor K-feldspar, biotite and opaque minerals, with quartz in the more differentiated rocks (Fig. 4D). Evidence of disequilibrium in the magma chamber is reflected by plagioclase with sieve texture and crystals zoning in amphibole and plagioclase (Fig. 4D, E, F). Usually, there is a cumulus assemblage of mafic phases, mainly amphibole and opaque minerals that could be interpreted as enclaves coming directly from the first stage of magma crystallization. The originally glassy groundmass is characterized by a fine grain association of plagioclase, quartz and in lesser proportion K-feldspar (Fig. 4E, F). Small hornblende crystals and grains of opaque minerals are also present.

\section{Age of the eruptive sequence}

The pyroclastic, volcanic and intrusive rocks interbedded and associated to the Iglesia Group sediments have been dated in previous work, with most of the ages ranging between Lower to Upper Miocene (Table 1). Earliest intrusive events comprises the Miocene Intrusives (22-20 Ma) at Llanos del Médano region,

We present new ${ }^{40} \mathrm{Ar} /{ }^{39} \mathrm{Ar}$ and $\mathrm{K} / \mathrm{Ar}$ ages carried out at the Geochronology Laboratory at SERNAGEOMIN, Chile. The results are summarized in table 2 and plotted in figure 2. An amphibole ${ }^{40} \mathrm{Ar} /{ }^{39} \mathrm{Ar}$ age of 14.9 \pm 1.3 Ma was obtained from an andesite at Cerro Puntas Negras (sample 201), while an amphibole $\mathrm{K}-\mathrm{Ar}$ age of $13.8 \pm 1.0$ was achieved in a dacite from Divisadero Sur (sample TOC 31). A biotite $\mathrm{K}$-Ar age of $12.0 \pm 1.9 \mathrm{Ma}$ corresponds to the base of the pyroclastic flow (sample C01) at the Iglesia Valley, near Rodeo, and another biotite K-Ar age of $8.3 \pm 1.3$ Ma comprise the upper part of the Ignimbrite flow at Iglesia Valley in Quebrada Morterito (sample TOC 09; Fig. 4B). Also, another amphibole K-Ar age of $4.6 \pm 0.8 \mathrm{Ma}$ was obtained from cerro Bola dacite (sample TOC 17; Fig. 4B).

Based on this new and the previously published geochronological information, added to the field observations, we can establish that volcanosedimentary activity was almost continuous between Middle to Upper Miocene in the Iglesia Valley depocenter, with a magmatic activity decreasing in intensity and frequency as the age decreases, to cease around Lower Pliocene ( $\sim \mathrm{Ma})$, the youngest age of magmatic activity registered in the area. First expression of this volcanic activity could be related to the shallow intrusives of Early Miocene age (22-20 $\mathrm{Ma}$ ) outcropping in the northern part of the Iglesia Valley area (Fig. 2).

\section{Geochemistry of Middle to Upper Miocene volcanic rocks}

Geochemical analyses were performed on 32 samples of the Middle to Upper Miocene (14.94.6 Ma) magmatic rocks with ages constrained by field relationship and available geochronological data. As mentioned in the petrographic description, pyroclastic rocks contain numerous juvenile comagmatic pumiceous fragments. To carry out the chemical analyzes, homogeneous samples without contents of pumiceous and/or lithic fragments were selected.

Whole rock major and trace element analyses were carried out at Activation Laboratories, Canada 

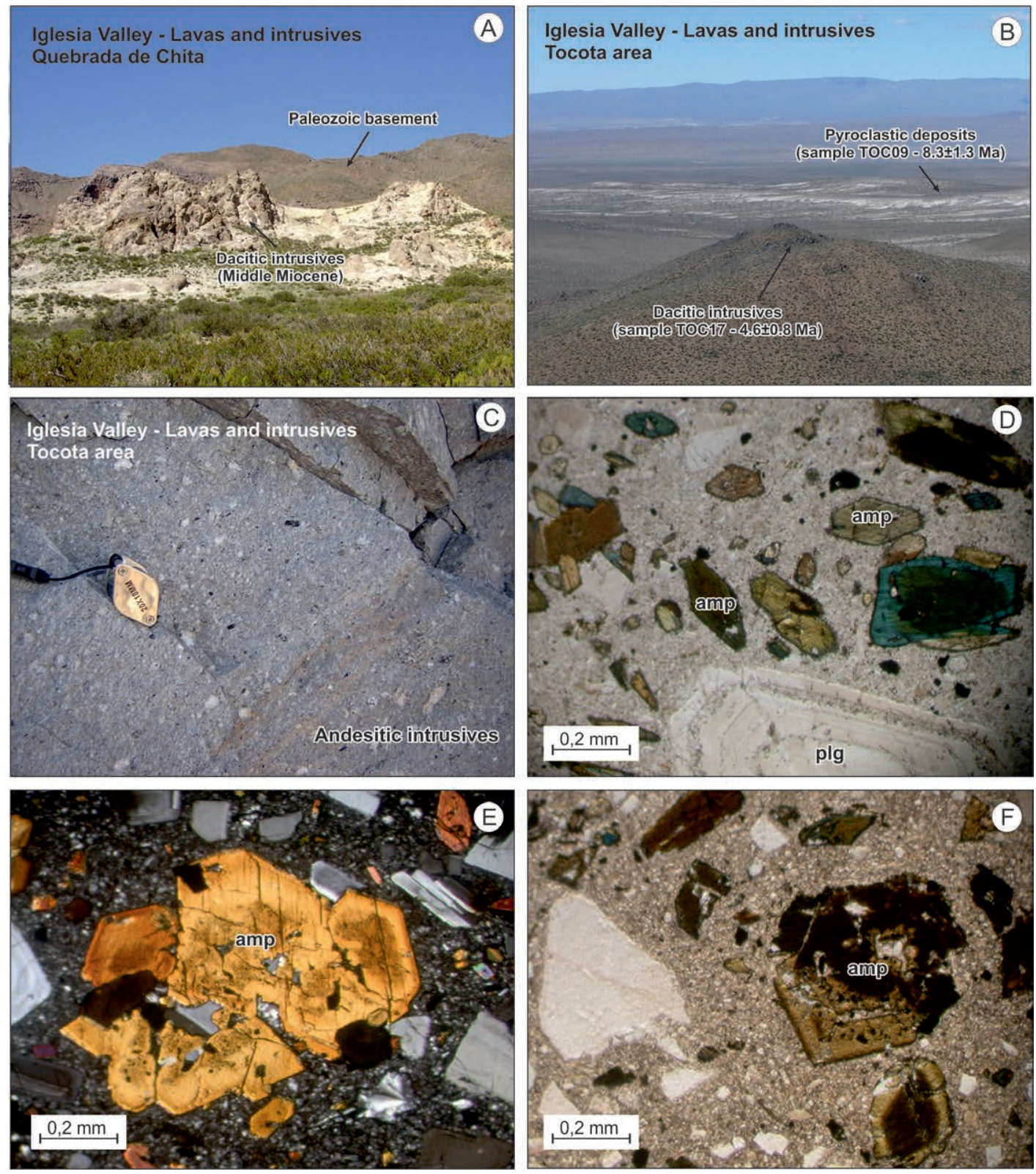

FIG. 4. Lava and intrusive rock within of the Lomas del Campanario Formation. A. Light colored dacitic intrusives outcropping in Quebrada de Chita, intruding Paleozoic basement; B. View to the southeast from Quebrada de Tocota; at the front, dacitic intrusive bodies, at the back, low relief pyroclastic deposits; C. Detail of plagioclase, hornblende-bearing andesite outcrops in Quebrada de Tocota; D. Andesite with porphyritic texture, with zoned and in sieve textured plagioclase (plg) and greenish amphibole (amp); E. Detail of a zoned amphibole phenocrysts in the dacitic intrusives, with quartz, alkali feldspar-rich groundmass; F. Porphyritic andesites with zoned amphibole and a partially clay-altered groundmass.

(www.actlabs.com (last visit 23-08-2017)). Analyzed samples of lavas and subvolcanic rocks are from Cerro Divisadero, Cerro Bola, Quebrada de Chita, Cerro Puntas Negras and Cerro Negro. Samples of pyroclastic rocks were obtained at Tocota, Bella Vista, Tudcum, Rodeo, Cuesta del Viento and other outcrops along the Iglesia valley (Fig. 2). Results of determinations and location of samples are summarized in Appendix. 
TABLE 1. COMPILATION OF PREVIOUS GEOCHRONOLOGICAL DATA FOR NEOGENE ARC-RELATED SEQUENCES FROM IGLESIA VALLEY, WESTERN PRECODILLERA.

\begin{tabular}{|c|c|c|c|c|}
\hline Location & Rock type & Method & Age (Ma) & Reference \\
\hline Llanos del Médano & Granite & $\mathrm{Rb} / \mathrm{Sr}$ (whole rock-biotite) & $22.4 \pm 0.1$ & Llambías et al. (1990) \\
\hline Llanos del Médano & Granite & $\mathrm{Rb} / \mathrm{Sr}$ (whole rock-biotite) & $21.2 \pm 0.1$ & Llambías et al. (1990) \\
\hline Llanos del Médano & Granite & $\mathrm{U} / \mathrm{Pb}$ (zircon) & $22.2 \pm 0.23$ & Jones et al. (2016) \\
\hline Llanos del Médano & Granite & $\mathrm{U} / \mathrm{Pb}$ (zircon) & $21.4 \pm 0.29$ & Jones et al. (2016) \\
\hline Llanos del Médano & Granodiorite & $\mathrm{U} / \mathrm{Pb}$ (zircon) & $20.4 \pm 0.31$ & Jones et al. (2016) \\
\hline Cerro Divisadero & Dacite & $\mathrm{K} / \mathrm{Ar}$ (plagioclase) & $18.3 \pm 2.5$ & Leveratto (1976) \\
\hline Cerro Negro & Dacite & $\mathrm{K} / \mathrm{Ar}$ (biotite) & $17 \pm 5$ & Leveratto (1976) \\
\hline Quebrada Chita & Andesitic porphyry & K/Ar (biotite) & $11.7 \pm 0.3$ & Sillitoe (1977) \\
\hline Cerro Puntas Negras & Pyroclastic rock & $\mathrm{K} / \mathrm{Ar}$ (not informed) & $11 \pm 0.5$ & Kay and Abruzzi (1996) \\
\hline Cerro Divisadero & Trachyandesite & $\mathrm{U} / \mathrm{Pb}$ (zircon) & $11.7 \pm 0.21$ & Jones et al. (2016) \\
\hline Cuesta del Viento & Dacitic tuff & Ar/Ar (amphibole) & $9.58 \pm 0.28$ & Alonso et al. (2011) \\
\hline Quebrada Chita & Dacite & $\mathrm{U} / \mathrm{Pb}$ (zircon) & $9.5 \pm 0.18$ & Jones et al. (2016) \\
\hline Quebrada Chita & Trachyandesite & $\mathrm{U} / \mathrm{Pb}$ (zircon) & $9.4 \pm 0.18$ & Jones et al. (2016) \\
\hline Cerro Bola & Andesite & $\mathrm{K} / \mathrm{Ar}$ (whole rock) & $8.8 \pm 0.3$ & Wetten (2005) \\
\hline
\end{tabular}

TABLE 2. NEW GEOCHRONOLOGICAL DATA OF NEOGENE ARC-RELATED ROCKS FROM IGLESIA VALLEY, WESTERN PRECORDILLERA.

\begin{tabular}{|c|c|c|c|c|c|}
\hline Sample & Location & Coordenates & Rock type & Method & Age (Ma) \\
\hline $\mathrm{CN} 201$ & Cerro Puntas Negras & $30^{\circ} 31^{\prime} 20^{\prime \prime} \mathrm{S} / 69^{\circ} 07^{\prime} 24^{\prime \prime} \mathrm{W}$ & Andesite & Ar/Ar (amphibole) & $14.9 \pm 1.3$ \\
\hline TOC31 & Divisadero Sur & $30^{\circ} 44^{\prime} 49^{\prime \prime} \mathrm{S} / 69^{\circ} 24^{\prime} 58^{\prime \prime} \mathrm{W}$ & Dacite & K-Ar (amphibole) & $13.8 \pm 1.0$ \\
\hline $\mathrm{C} 01$ & Rodeo & $30^{\circ} 12^{\prime} 22^{\prime \prime} \mathrm{S} / 69^{\circ} 04^{\prime} 06^{\prime \prime} \mathrm{W}$ & Andesitic tuff & K-Ar (biotite) & $12.0 \pm 1.9$ \\
\hline TOC09 & Qda. Morteritos (Tocota) & $30^{\circ} 44^{\prime} 38^{\prime \prime} \mathrm{S} / 69^{\circ} 30^{\prime} 38^{\prime \prime} \mathrm{W}$ & Dacitic tuff & K-Ar (biotite) & $8.3 \pm 1.3$ \\
\hline TOC17 & Cerro Bola (Tocota) & $30^{\circ} 39^{\prime} 33^{\prime \prime} \mathrm{S} / 69^{\circ} 31^{\prime} 16^{\prime \prime} \mathrm{W}$ & Dacite & K-Ar (amphibole) & $4.6 \pm 0.8$ \\
\hline
\end{tabular}

The pyroclastics rocks sampled in different localities are not differentiated in the diagrams, while the lava flows and intrusive rocks are differentiated within the plots to show some variable chemical behavior between localities. Some tufts in Rodeo area have unusually high LOI values related to minerals formed by vitreous matrix devitrification, Appendix.

The total alkali-silica plot (Fig.5A) show a series that vary from basaltic-andesite to rhyolite, with silica content ranging between $53.22 \mathrm{wt} \%$ and 69.92 $\mathrm{wt} \%$. All samples plot within the sub-alkaline field, except for one altered basaltic lava flows of Quebrada Aguaditas and one altered pyroclastic rock from
Rodeo area (Fig. 5A). The alumina saturation indices indicate that the series is dominantly metaluminous to slightly peraluminous with $\mathrm{A} / \mathrm{CNK}<1.1$ (Fig. 5B).

Plot of $\mathrm{K}_{2} \mathrm{O}$ versus $\mathrm{SiO}_{2}$ (Fig. 5C) shows that most of the analyzed rocks have medium to high $\mathrm{K}_{2} \mathrm{O}$ content, being pyroclastic rocks near or within the high-K field. The samples that plot in or near the medium-K field are generally from the early to midLate Miocene lavas from Cerro Negro, Cerro Bola and Divisadero; while lavas from Quebrada de Chita and Quebrada Aguaditas are within the high-K field.

In the N-MORB normalized (Pearce, 1983) multielement diagrams (Fig. 6A) all samples exhibit an 

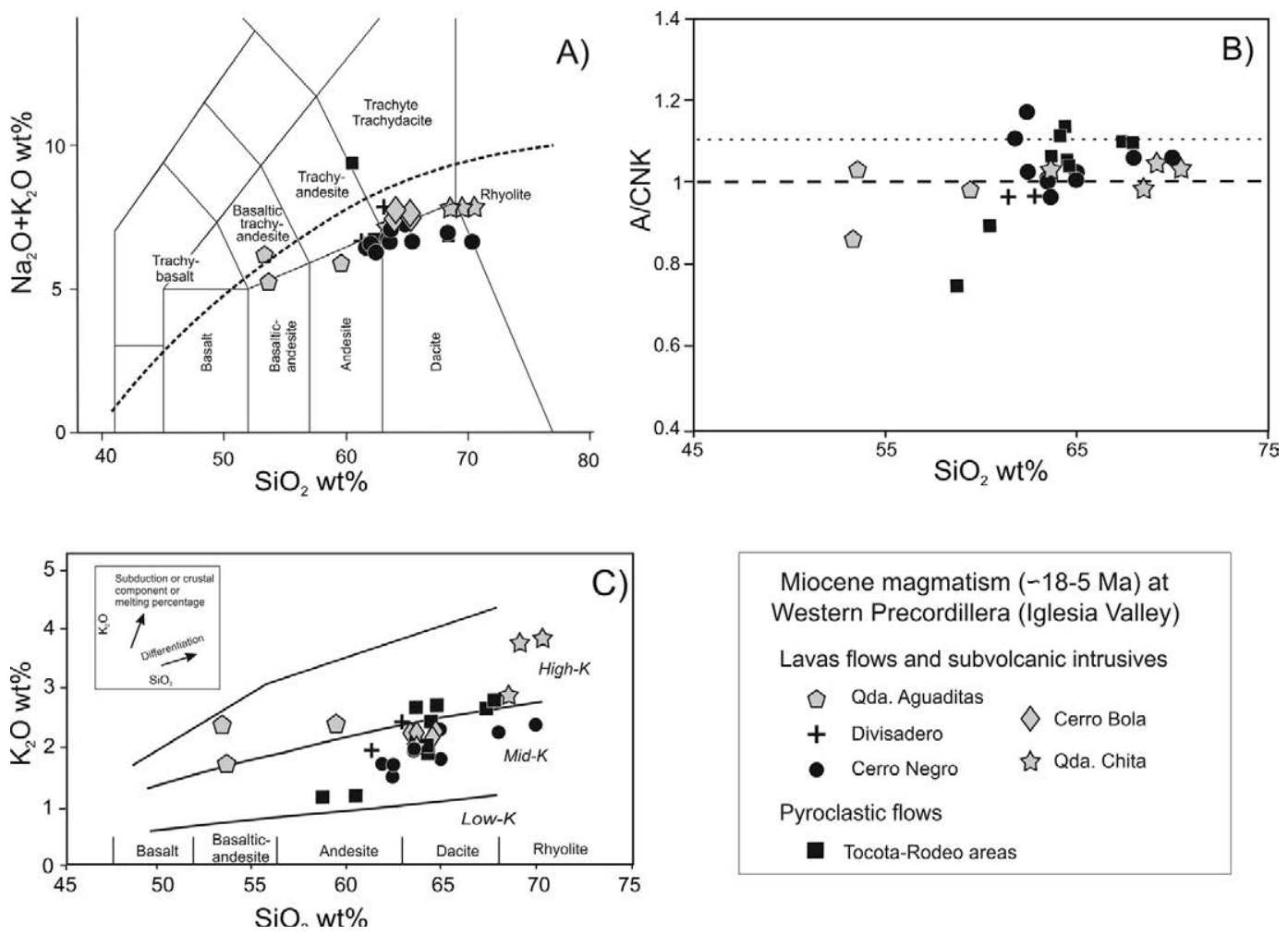

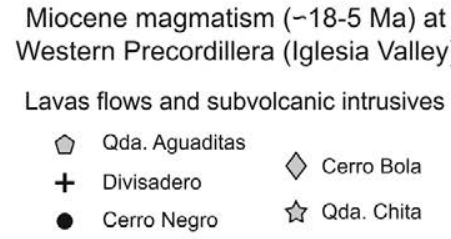

Pyroclastic flows

- Tocota-Rodeo areas

FIG. 5. Geochemical features of Miocene arc-related pyroclastic rocks and lavas from Iglesia Valley, Western Argentine Precordillera. A. Total alkali versus silica classification diagram (Le Maitre et al., 1989); B. Plots of molar Al ( $\mathrm{Na}+\mathrm{K}+\mathrm{Ca}$ ) ratios versus silica content, showing a metaluminous signature; C. $\mathrm{K}_{2} \mathrm{O}$ versus $\mathrm{SiO}_{2}$ diagram shows a medium to high-K signature for pyroclastic rocks, lavas and subvolcanic intrusives of the Iglesia Valley area, with a general trend for subduction or crustal components (Kay et al., 2013).

enrichment in $\mathrm{K}_{2} \mathrm{O}, \mathrm{Sr}, \mathrm{Rb}$, Th and particularly $\mathrm{Ba}$ and negative $\mathrm{Ta}$ and $\mathrm{Nb}$ anomalies. They also show negative $\mathrm{TiO}_{2}$ anomalies and depletions in HREE relative to N-MORB as is expected in active continental margin patterns (Pearce, 1983). In this sequence, the low values of $\mathrm{TiO}_{2}$ (normalized values are $<0.56$, except for 3 samples from Quebrada Aguaditas) is a distinctive behavior of this element where Fe-Ti bearing oxides crystallization are coetaneous phases with amphibole and plagioclase during fractional crystallization (Rollinson, 1993) (Fig. 6A).

Another feature observed in this diagram is the regular pattern of LILE and HFSE that indicates a relative homogeneity in magmas evolution, regardless their silica content.

$\mathrm{La} /$ Ta versus $\mathrm{Ba} / \mathrm{Ta}$ ratios are useful indicators to evaluate typical characteristics of arc-related components (Fig. 6B). A strong enrichment in $\mathrm{Ba}$ is noted in all the Miocene rocks, especially in samples from Divisadero (Ba/Ta $>1,450-1,750)$, Quebrada de
Chita $(\mathrm{Ba} / \mathrm{Ta}>1,650-2,200)$, Quebrada Aguaditas $(\mathrm{Ba} / \mathrm{Ta}>570-2,300)$ and Cerro Bola $(\mathrm{Ba} / \mathrm{Ta}>1,450$ 2,080). Particularly, when comparing Iglesia Valley magmatic rocks with those from the Cordillera Frontal, we noticed that lavas and pyroclastic facies from Lomas del Campanario Unit have higher $\mathrm{Ba} / \mathrm{La}$ ratios (21-79.5) than main arc volcanism (13.3-45.9; e.g., Kay et al., 1991; Litvak et al., 2007), although geochemical signatures from both magmatic belts remains compatible with an arc-related setting (Fig. 6B).

The chondrite normalized REE patterns of the analyzed samples (Fig. 6C) show La contents that vary from 32.6 to 102 times chondrite values. $\mathrm{Yb}$ contents vary from 2.4 to 9.4 times chondrite values. The geochemical features exhibit variable degrees of HREE depletion. In detail, $\mathrm{La} / \mathrm{Yb}$ ratios of pyroclastic rocks are between 22.6 and 27 and $\mathrm{Sm} / \mathrm{Yb}$ from 4.5 to 4.7; lava flows from Cerro Negro show $\mathrm{La} / \mathrm{Yb}$ between 18.3 and 28.4, and $\mathrm{Sm} / \mathrm{Yb}$ from 4.1 to 6.0 ; lava flows from Quebrada Aguaditas have La/Yb 

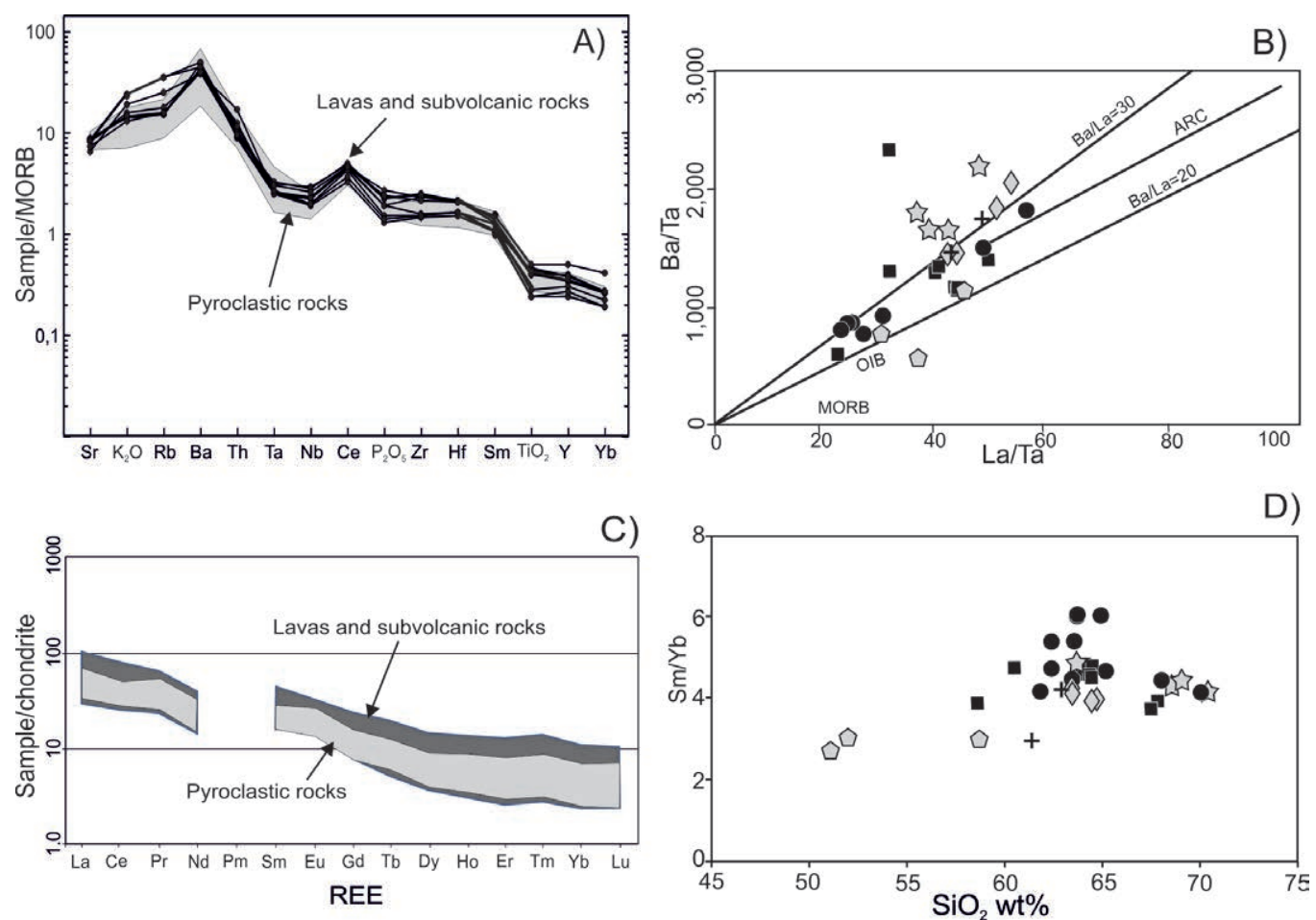

FIG 6. A. MORB normalized (Pearce, 1983) trace element pattern for pyroclastic rocks (grey pattern) from Rodeo and Tocota areas, and lavas and subvolcanic rocks (black dots) from Chita, Cerro Bola, Cerro Negro, Aguaditas and Divisadero; both groups show a similar volcanic arc-related behavior in their trace elements; B. Ba/Ta versus $\mathrm{La} / \mathrm{Ta}$ showing the volcanic arc-related distribution of the samples; C. Chondrite normalized REE pattern (Nakamura, 1974) for pyroclastic rocks, lavas and subvolcanic intrusives; D. $\mathrm{Sm} / \mathrm{Yb}$ versus $\mathrm{SiO}_{2}$ diagrams showing a relative similar $\mathrm{Sm} / \mathrm{Yb}$ ratios for the intermediate to silicic rocks (62-67 $\mathrm{SiO}_{2} \mathrm{wt} \%$ ), except for some dacites from Cerro Negro. Symbols are the same as figure 5.

between 10.1 and 17.9 and $\mathrm{Sm} / \mathrm{Yb}$ from 2.7 to 3.7 ; lavas from Divisadero show $\mathrm{La} / \mathrm{Yb}$ from 15.6 to 23.4 and $\mathrm{Sm} / \mathrm{Yb}$ from 3.0 to 4.2; lavas from Quebrada de Chita have $\mathrm{La} / \mathrm{Yb}$ varying between 23.6 to 27.9 and $\mathrm{Sm} / \mathrm{Yb}$ from 4.1 to 4.5 and finally, Cerro Bola show $\mathrm{La} / \mathrm{Yb}$ values from 24.2 to 25.7 and $\mathrm{Sm} / \mathrm{Yb}$ from 3.9 to $4.3 . \mathrm{Sm} / \mathrm{Yb}$ ratios between 4 and 6 exhibits for most of the analyzed samples (Fig. 6D) is consider generally as a signal of $\mathrm{Yb}$ retention in residual mineral assemblage in equilibrium with magmas, with amphibole to garnet transition (Hildreth and Moorbath, 1988) (Fig. 6D).

Lavas and pyroclastic rocks from Iglesia Valley Basin present constant $\mathrm{Rb} / \mathrm{Sr}$ ratio for positive $\mathrm{Eu}$ anomalies, with $\mathrm{Eu} / \mathrm{Eu}^{*}$ average of 1.2, with a range from 1.01 to 1.33 . Only a few samples show higher positive Eu anomaly, (sample 2 and 4 from Cerro Negro lavas with $\mathrm{Eu} / \mathrm{Eu}^{*}$ of 1.63 and 1.70, respectively) that could be interpreted because of moderate plagioclase accumulation (Rollinson, 1993). The volcanic rocks are LREE enriched, most of samples have HREE depletions, low $\mathrm{Yb}(\leq 1.9 \mathrm{ppm})$ and $\mathrm{Y}(<18 \mathrm{ppm})$ contents. In general, and particularly in Cerro Negro lavas, the $\mathrm{La} / \mathrm{Yb}$ ratio increase with the degree of differentiation; these samples have high $\mathrm{Sr}$ contents and high to moderate $\mathrm{Sr} / \mathrm{Y}$ ratios (>20) (Fig. 7A) and high $\mathrm{Sr} / \mathrm{Yb}$ ratios (Fig. 7B). The volcanic rocks with high $\mathrm{Sr} / \mathrm{Y}$ and high $\mathrm{La} / \mathrm{Yb}$ ratios display also high $\mathrm{Gd} / \mathrm{Yb}$ ratios, showing geochemical affinity with adakite-like rocks, according to Mori et al. (2007) (Fig. 7C, D).

Lava flows of Quebrada de Chita and Cerro Negro show the highest $\mathrm{La} / \mathrm{Yb}$ ratios, indicating enrichment in LREE compared to the coetaneous pyroclastic rocks from diverse outcrops along the Iglesia Valley Basin.

$\mathrm{La} / \mathrm{Yb}$ versus $\mathrm{La} / \mathrm{Sm}$ ratio plot (Fig. 7E) show the behavior of the Iglesia Valley Basin rocks together 

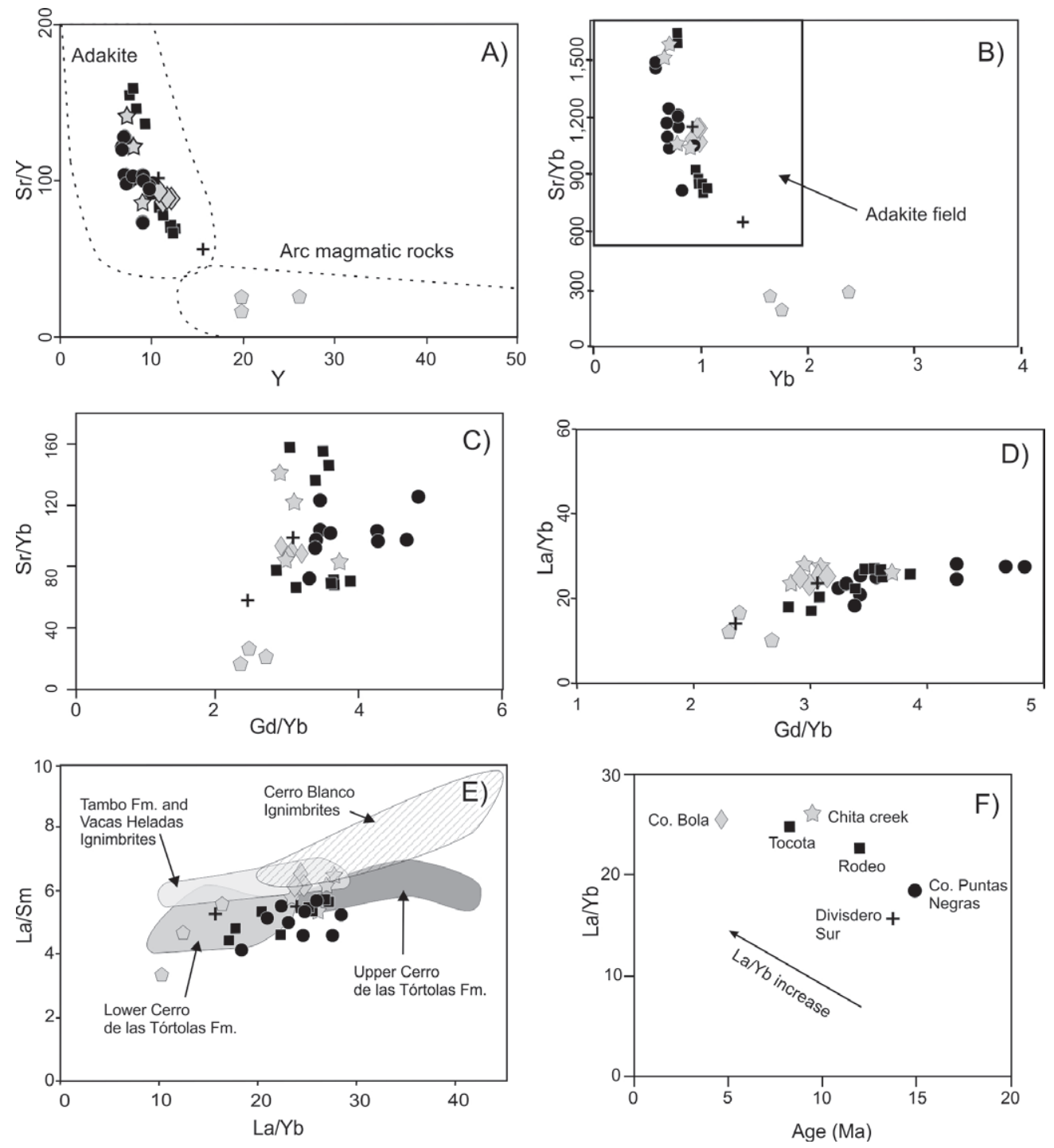

FIG. 7. A. Adakite signature for Miocene Iglesia Valley magmatic rocks according to Sr/Y versus $\mathrm{Y}$ plot (Castillo, 2012); B. Sr/Yb ratio versus $\mathrm{Yb}$ diagram showing adakitic field (e.g., Defant and Drummond, 1990; Martin et al., 2005); C. Cerro Negro lava flows and Tocota-Rodeo pyroclastics rocks show the higher $\mathrm{Sr} / \mathrm{Yb}$ and $\mathrm{Gd} / \mathrm{Yb}$ ratios, indicating a more pronounced adakitic geochemical affinity; D. La/Yb versus $\mathrm{Gd} / \mathrm{Yb}$ diagram showing adakitic like ratios according to Mori et al. (2007); E. La/ $\mathrm{Yb}$ versus $\mathrm{La} / \mathrm{Sm}$ plot for Iglesia Valley Miocene magmatism and coetaneous volcanic rocks from the main arc over the Pampean flat slab (data from Litvak et al., 2007), and rocks from Miocene arc in Southern Puna (data from Montero et al., 2010); F. $\mathrm{La} / \mathrm{Yb}$ versus age diagram for the Iglesia Valley magmatic rocks dated in this work, they display an increase of La/ $\mathrm{Yb}$ ratio in younger samples (data from table 2 and Appendix; age for Chita sample corresponds to Jones et al., 2016). Symbols are the same as figure 5 .

with volcanic rocks of similar age from Cerro de las Tortolas and Tambo Formations and from the younger Vacas Heladas Ignimbrite, all of them located in Cordillera Frontal, which represent the contemporary main volcanic-arc activity to the west. Different groups of volcanic rocks can be established, according to their trace elements behaviors, which reflect the variable residual mineral phases that fractionated at depth in equilibrium with magma (Hildreth and Moorbath, 1988). Increasing $\mathrm{La} / \mathrm{Yb}$ ratios at a given $\mathrm{La} / \mathrm{Sm}$ ratio are best explains by increasing amounts of amphibole and garnet formed at higher pressure 
in the residual mineralogy (Hildreth and Moorbath, 1988). In these scenario, the highest $\mathrm{La} / \mathrm{Yb}$ ratios from Iglesia Valley Basin are lower than equivalents rocks of same age from the more fractionated lavas from Upper Miocene Cerro de las Tórtolas (13-10 Ma) (Fig. 7E).

Overall, considering ages and variations in the $\mathrm{Sm} / \mathrm{Yb}$ and $\mathrm{La} / \mathrm{Yb}$, evolution of Iglesia Valley Basin magmas was firstly controlled by amphibole fractionation. As the time progress, the increase in these ratios (Appendix) would suggest a gradual increase in pressure conditions, with garnet as residual phase in magma equilibration site.

\section{Discussion}

\subsection{Eastern Expansion of Arc-Related Magmatism}

At the latitude of $29^{\circ} 30^{\prime}-30^{\circ} 00^{\prime} \mathrm{S}$, magmatic activity developed to the east of the Miocene main volcanic arc is represented by subvolcanic intrusives and related lava flows and pyroclastic deposits (Lomas del Campanario Formation), cropping out in the Central and Western part of the Precordillera (Fig. 2). First record of Neogene magmatism in a back arc position range between 22 to $20 \mathrm{Ma}$, represented by the Miocene Intrusives at the northern part of the Iglesia Valley. By the same time, main arc activity was represented by the latest stages of the Doña Ana Group magmatism, although pick of Neogene arc activity is represented by the lower section of the Cerro de las Tortolas Formation ( 16-13 Ma) with mostly andesitic, medium-K calc-alkaline rocks (e.g., Maksaev et al., 1984; Bissig et al., 2003; Kay et al., 1991, 1999; Litvak et al., 2007; Jones et al., 2016). Arc-related magmatism by this time was also developed towards the foreland, with the coetaneous intermediate subvolcanic and lavas flows cropping out in Cerro Negro area, with ages around $15 \mathrm{Ma}$.

Later, during the Middle to Late Miocene (13$10 \mathrm{Ma})$, arc magmatic activity is represented by a more evolved dacitic calc-alkaline volcanism from the upper section of Cerro de las Tórtolas Formation and the dacitic to rhyolitic pyroclastic deposits from Tambo Formation (Bissig et al., 2003; Kay et al., 1991, 1999; Litvak et al., 2007; Jones et al., 2016). Contemporaneously, arc-related magmatism was developed in an easternmost position, represented by the pyroclastic deposits and younger subvolcanic bodies cropping out in the eastern margin of the
Cordillera del Colangüil, along the Iglesia Valley, ranging in age from 11 to $9 \mathrm{Ma}$ (Fig. 2).

Afterward and due to the shallowing of the subducted slab, volcanic activity was strongly reduced by Latest Miocene in the former main arc, with the emplacement of the rhyolitic tuffs from Vacas Heladas Ignimbrites as the last significant arc volcanism, with $\mathrm{K}-\mathrm{Ar}, \mathrm{Ar} / \mathrm{Ar}$ and $\mathrm{U}-\mathrm{Pb}$ ages ranging between 5.5 to 6.0 Ma (Ramos et al., 1987; Kay et al., 1991; Bissig et al., 2001; Kay and Mpodozis, 2002; Litvak et al., 2007; Jones et al., 2016).

Magmatic activity in a back arc position also continued during Late Miocene. This arc-related volcanism, now cropping out in Western Precordillera, was reported as young as $\sim 8 \mathrm{Ma}$ (Wetten, 2005). However, given the new ages in this work, eastern expansion of arc magmatism was presumably continuous until Early Pliocene, as evidence by the andesitic to dacitic subvolcanic bodies exposed in Arroyo Chita with ages as young as of 4.6 Ma.

\subsection{Variable Geochemical Behavior in Neogene arc-related magmas}

The Iglesia Valley volcanic rocks show a general trend for increasing subduction or crustal components, or increasing melting percentage according to Kay et al. (2013) (Fig. 5C). Overall, all of the samples are LREE-enriched (La/Sm: 3.7-6.5) with respect to HREE (Sm/Yb: 2.2-6.0) (Fig. 8A) and they display steep chondrite normalized REE patterns. The observed changes in the value of $\mathrm{Sm} / \mathrm{Yb}$ ratio are compatible with increase in pressure at the magma equilibration site and retention of HREE in residual mineralogy, particularly garnet, as suggested by $\mathrm{Sm} / \mathrm{Yb}$ ratios $>4$ (e.g., Hildreth and Moorbath, 1988; Kay et al., 1991). Higher values of the $\mathrm{Sm} / \mathrm{Yb}$ ratio are observed in the rocks of the Iglesia Valley when compared with their counterparts of the Frontal Cordillera (volcanic rocks of lower Cerro de las Tórtolas Formation and Vacas Heladas Ignimbrite), although the Iglesia Valley volcanic rocks show a normalized REE pattern with relatively minor LREE enrichment. The volcanic rocks of the main arc represented by the upper part of Cerro de las Tórtolas Formation contain the highest $\mathrm{Sm} / \mathrm{Yb}$ ratios (Fig.8A) that show a passage to garnet as a residual mineral, which is interpreted as a gradual increase of the magma equilibrium depth within the crust (Kay et al., 1991, 1999; Bissig et al., 2003; Litvak et al., 2007). 

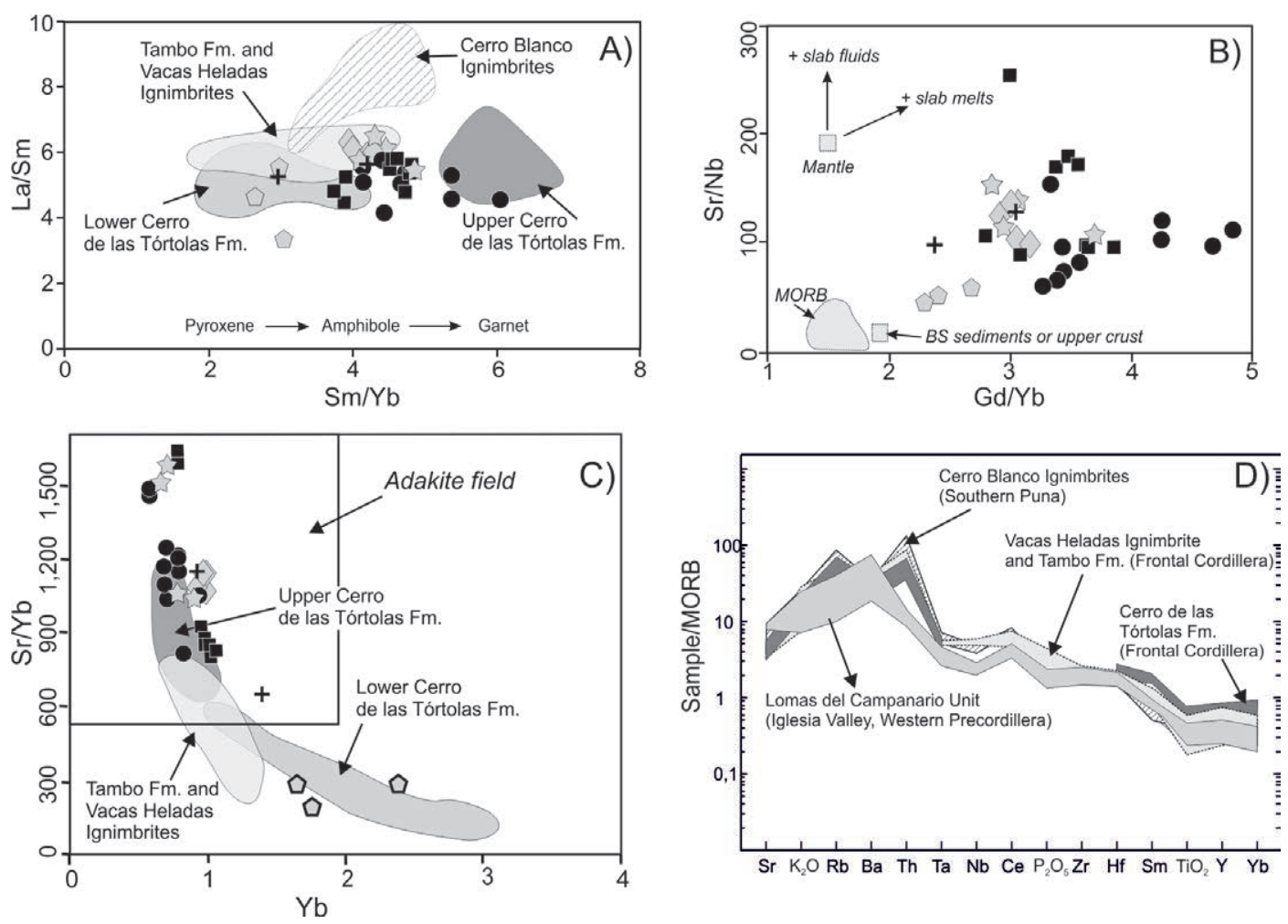

FIG. 8. A. La/Sm versus $\mathrm{Sm} / \mathrm{Yb}$ plot for Miocene Iglesia Valley magmatic rocks, showing an increase in heavy REE ratio attributed to change from amphibole to garnet as residual mineral assemblage in magma equilibrium site; data from coetaneous rocks from main volcanic arc in Cordillera Frontal and Upper Miocene Southern Puna magmatism is shown for comparison (data from Litvak et al., 2007; Montero et al., 2010); B. Sr/Nb versus $\mathrm{Gd} / \mathrm{Yb}$ diagram according to Mori et al. (2007) as indicative of different mechanism for elements recycling that could contributed to the petrogenesis of the rocks. (BS) bulk composition of the subducted sediments from DSDP Site 487 (LaGatta, 2003); C. Sr/Yb versus $\mathrm{Yb}$ plot showing the adakitic signature of Miocene Iglesia Valley magmatic rocks relative to the main volcanic arc rocks to the west; note that the rocks of Upper Cerro de las Tórtolas Formation and part of Vacas Heladas Ignimbrite and Tambo Formation (Middle to Upper Miocene) from the main volcanic arc share adakitic signature with coetaneous magmatic rocks from Iglesia Valley area (Western Precordillera) (data from Litvak et al., 2007); D. MORB normalized (Pearce, 1983) incompatible element abundances of Lomas del Campanario Formation magmatic rocks and coetaneous volcanic rocks from the main volcanic arcs in Cordillera Frontal (Litvak et al., 2007) and Southern Puna (Montero et al., 2010). Note that the volcanic rocks from main volcanic arc share a similar enrichment in $\mathrm{Rb}$ and $\mathrm{Th}$, and are depleted in $\mathrm{Sr}$, while rocks from Lomas del Campanario Formation show a different pattern of enrichment with higher values of $\mathrm{Sr}$ and $\mathrm{Ba}$ and more depleted in $\mathrm{Ta}$ and $\mathrm{Nb}$. Symbols are the same as figure 5 .

The petrography, geochemistry and ages of the volcanic and pyroclastic rocks located in the Iglesia Valley have a continental magmatic arc signature comparable to those corresponding to the coetaneous main volcanic arc front at the nearby latitude, towards the west. The arc-related rocks from both magmatic areas show a sustained increase in the $\mathrm{La} / \mathrm{Yb}$ ratio with decreasing age (Fig. 7F). The mantle-wedge melts that gave origin to Western Precordillera magmatic rocks would also have evolved through the crust, with a gradual variation in the residual mineral phases related to the progressive depth of magma equilibrium site. In this case, the increase in crustal thickness resulted from the tectonic compressive regime, would be related to the development of the Miocene La Tranca thrust (Alonso et al., 2011).

Particular geochemical characteristics are seen in some of the lavas located in Western Precordillera (Tocota-Rodeo area, Quebrada de Chita and Cerro Negro volcanic rocks), given by their high $\mathrm{Sr} / \mathrm{Y}$ and $\mathrm{La} / \mathrm{Yb}$ ratios at high $\mathrm{Gd} / \mathrm{Yb}$ ratios (Fig. $7 \mathrm{C}$ and $\mathrm{D})$. These rocks also show high $\mathrm{Sr} / \mathrm{Nb}$ versus 
$\mathrm{Gd} / \mathrm{Yb}$ ratios (Fig. 8B). These features represent a geochemical affinity with adakite-like rocks (e.g., Defant and Drummond, 1990; Mori et al., 2007; Moyen, 2009).

The term adakite was define by Defant and Drummond (1990) to represent volcanic rocks of andesitic to dacitic compositions with $\mathrm{SiO}_{2}>56$ $\mathrm{wt} \%, \mathrm{Al}_{2} \mathrm{O}_{3}>15 \%, \mathrm{Sr}>400 \mathrm{ppm}$, high $\mathrm{Sr} / \mathrm{Y}$ and La/ $\mathrm{Yb}>20$. Among the main processes that originate these geochemical characteristics would be the partial melting of subducted oceanic crust and/or the partial melting of lower continental crust (Kay, 1978; Defant and Drummond, 1990; Martin et al., 2005; Kay et al., 2005; Moyen, 2009). There are others numerous explanations for the origin of the adakitic rocks, the tectonic setting in which occur and their relationships with the compressive tectonic events (e.g., Castillo, 2012). In consequence, the term adakite is used here as a descriptive term to refer to the rocks with the adakitic trace element characteristics: HREE depletions and high $\mathrm{Sr}$ concentrations, high $\mathrm{Sr} / \mathrm{Y}$ and $\mathrm{La} / \mathrm{Yb}$ ratios (Defant and Drummond, 1990) despite of its genesis and settings (Kamvong et al., 2014).

Some Middle to Upper Miocene volcanic rocks of the main arc that crop out in the Valle del Cura area (Cerro de las Tórtolas Formation) also show a strong adakitic signature (Fig. 8C, Kay and Mpodozis, 2002; Litvak et al., 2007; Goss et al., 2013; Jones et al., 2016). These authors assigned their origin to the input of asthenospheric wedge derived magmas that interact with a thickened crust. Late Miocene volcanic suites in Western Precordillera with similar adakitic affinity could reflect the eastward expansion of arc magmatism with astenospheric-wedge derived melts due to dehydrations fronts located further east to the main arc (Ramos and Folguera, 2009), also interacting with a thickened crust.

$\mathrm{Sr} / \mathrm{Yb}$ ratios of Quebrada de Chita and Cerro Negro volcanic rocks are higher than the adakitic volcanic rocks of Cerro de las Tortolas in the main arc. The differences in the adakitic signal intensity (Fig. 8C) could be ascribed to the subduction and crustal variable components involved in its formation and related to their positions within the regional tectonic setting.

During the Miocene, main arc influence was expanded far into the back arc area, as shown in Western Precordillera arc magmas. Increase in crustal thickness during the Miocene lead to an increase in crustal components contributions in the mantle wedge-derived melts with time, particularly evidenced in the Upper Miocene rhyolitic magmas from the main arc (Kay et al., 1991, 1999; Litvak et al., 2007; Jones et al., 2016). However, there are several ways to add on crustal components: either by crustal contamination of mantle derived magmas through their upward evolution within the crust or into the magma source by sediment subduction and/or fore-arc subduction erosion processes (Stern, 1991, 2011; Kay et al., 2005; Goss et al., 2013).

The N-MORB normalized trace elements from Neogene arc-related rocks in the main arc and its eastern expression exhibit an enrichment in $\mathrm{K}_{2} \mathrm{O}, \mathrm{Sr}, \mathrm{Rb}, \mathrm{Th}$ and particularly Ba (Pearce, 1983); however, Lomas del Campanario Formation (Western Precordillera) have remarkable higher $\mathrm{Sr}$ and $\mathrm{Ba}$ content and are more depleted in $\mathrm{Rb}$ and $\mathrm{Th}$ compared to those from the Valle del Cura (Cerro de la Tórtolas Formation and Vacas Heladas Ignimbrite at Cordillera Frontal) rocks sequence (Fig. 8D). These differences show that the mantle derived magmas at the back arc position were enriched not only by subduction related fluids, but also by crustal components that particularly added the distinguished $\mathrm{Sr}, \mathrm{Ba}, \mathrm{Rb}$ and Th composition. This characteristic suggests differences in the crustal components affecting main arc magmas and it eastward expression, which has been explained as the result of different basement composition underlying both areas (Fig. 9) (Poma et al., 2014). In accord, previous $\mathrm{Nd}-\mathrm{Pb}$ isotopic models for Precordillera magmas (Kay et al., 1996) and more recently $\mathrm{O}-\mathrm{Hf}$ zircon isotopic signature, together with the inherited zircon ages of the Neogene arc-related magmas across the Pampean flat slab region (Jones et al., 2015), reflect a more likely Permo-Triassic basement as the of contamination source for the main arc magmas and a Grenville one for Precordillera volcanism.

If it is accepted that Iglesia Valley Basin configuration coincides with the northern part of the trace of the suture between Chilenia and western proto-Gondwana terranes, the geochemical characteristics of the volcanism of Western Precordillera record the input of material removed from a mafic lower crust, in contrast with the source characteristics of the main arc magmatism in Cordillera Frontal (Fig. 9).

Considering the variable behavior of the incompatible elements in the main arc and Western Precordillera lavas nearby $30^{\circ} 30^{\prime} \mathrm{S}$, we compared 


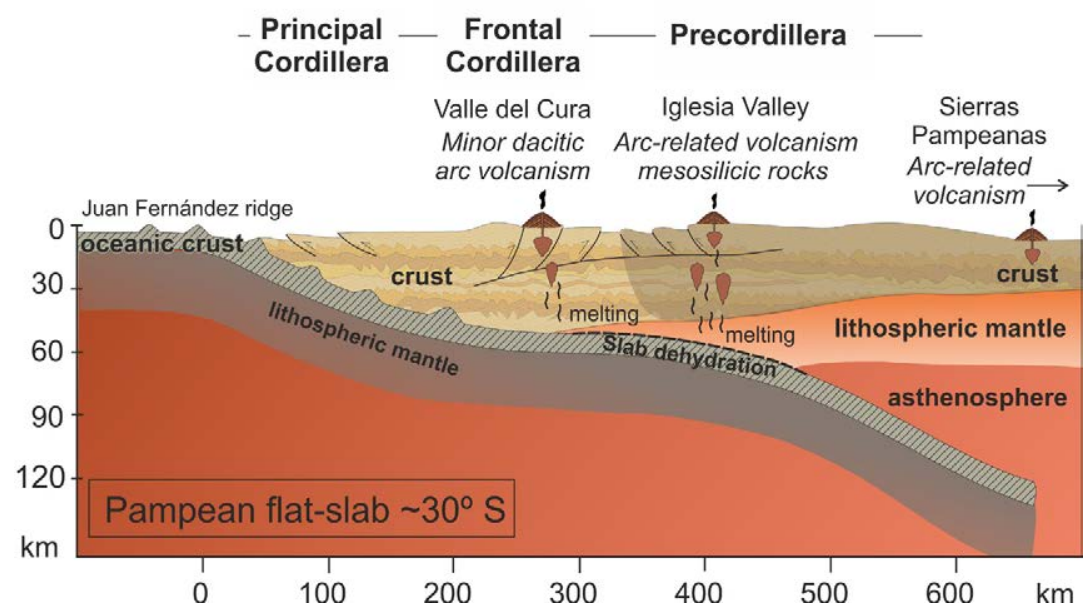

FIG. 9. Schematic geodynamic model for the present-day Pampean flat slab segment during Late Miocene. Note the eastward expansion of arc-related volcanism from Cordillera Frontal to Precordillera. Variable composition of continental crust contribution is inferred by the trace element behavior from arc-derived magmas in each setting (see text for further discussion). (Based on Litvak et al., 2007; Jones et al., 2016).

these rocks with the coetaneous magmatic arc in Puna Austral, particularly with the intermediate volcanic rocks from Cerro Blanco unit (Montero López et al., 2010) (Fig. 8D). This comparison shows a trace element affinity, related to crustal contributions (such as $\mathrm{Sr}, \mathrm{Ba}, \mathrm{Rb}$ and $\mathrm{Th}$ ) between the Valle del Cura main arc rocks and Cerro Blanco volcanites arc suites in Puna Austral (Fig. 8D), which could suggest similar crustal composition affecting arc magmatism. On the other hand, no particular correlation is seen between main arc sequences in Puna Austral and arc-related rocks in Western Precordillera.

\section{Concluding Remarks}

Geochemical and geochronological data and geographical location of the Neogene volcanic rocks exposed in the Iglesia Valley Basin allow identifying that the volcanic arc magmatic activity during the Miocene was expanded notably to the East relative to the location of the main arc at Valle del Cura, Western area of Cordillera Frontal. Expansion of volcanic arc activity towards Western Precordillera is the result of the diminishing of the Nazca plate subduction angle and its gradual flattening, since Middle Miocene.

With the availability of the ages of volcanic and pyroclastic sequences interbedded within the Iglesia Valley Basin it is possible to assess the development of an almost continuous magmatic event since $22 \mathrm{Ma}$, which decrease in intensity and frequency with time, to cease around $4 \mathrm{Ma}$.

Lomas del Campanario Formation lavas and pyroclastic rocks have a trace element characteristic that include HREE depletions and high $\mathrm{Sr}$ concentrations, with higher $\mathrm{Sr} / \mathrm{Y}$ and $\mathrm{La} / \mathrm{Yb}$ ratios in the younger rocks, showing an increase of pressure condition in magma equilibration within the crust by this time, as also registered in main arc volcanic rocks to the west. However, arc-related rocks in both areas reflect crustal variable components as reflected by its different geochemical LILE composition. Thus, it is interpreted that the cause of these geochemical differences between Iglesia Valley Basin rocks and the main arc in Valle del Cura sequences lay in the heterogeneous composition of the underlying crust that affected mantle derived melts in both magmatic areas across the present-day Chilean-Pampean flat slab region, during Neogene times.

\section{Acknowledgments}

This research was supported by grant from the Universidad de Buenos Aires to SP(UBACYT 20020100100520 and 20020130100628BA). We acknowledge L. Fernández Paz for the collaboration in edition of the work. We are grateful for the valuable revisions of the editor Dr. W. Vivallo, Dr. J. Muñoz-Bravo and an anonymous reviewer that improve the manuscript. 


\section{References}

Alonso, M.S.; Limarino, C.O.; Litvak, V.D.; Poma, S.M.; Suriano, J.; Remesal, M.B. 2011. Paleogeographic, magmatic and paleo environmental scenarios at $30^{\circ} \mathrm{S}$ during the Andean orogeny: Cross sections from the volcanic-arc to the orogenic front (San Juan, Argentina). In Cenozoic Geology of the Central Andes of Argentine (Salfity, J.A.; Marquillas, R.A.; editors). SCS Publisher: 23-45. Salta.

Aparicio, E.P. 1984. Geología de San Juan. Universidad Nacional de San Juan: 167 p. San Juan.

Beer, J.A.; Allmendinger, R.W.; Figueroa, D.E.; Jordan, T.E. 1990. Seismic stratigraphy of a Neogene Piggyback Basin, Argentina. American Association of Petroleoum, Geologists Bulletin 74 (8): 1183-1202.

Bercowski, F. 1993. Facies piroclásticas en el terciario del Valle de Iglesia, Provincia de San Juan, Argentina. In Congreso Geológico Argentino, No. 12, y Congreso de Exploración de Hidrocarburos, No. 2, Actas 4: 206-215. Mendoza.

Bissig, T.; Clark, A.H.; Lee, J.K.W.; Heather, K.B. 2001. The Cenozoic history of volcanism and hydrothermal alteration in the Central Andean flat-slab region: New ${ }^{40} \mathrm{Ar}-{ }^{39} \mathrm{Ar}$ constraints from the El Indio-Pascua $\mathrm{Au}$ -Ag-Cu belt, 29²0'-30³0'S. International Geology Review 43: 312-340.

Bissig, T.; Clark, A.H.; Lee, J.K.; von Quadt, A. 2003. Petrogenetic and metallogenetic responses to Miocene slab flattening: new constraints from the El IndioPascua Au-Ag-Cu belt, Chile/Argentina. Mineralium Deposita 38: 844-862.

Cardó, R.; Díaz, I.N. 1999. Hoja Geológica 3169-I, Rodeo, Provincias de San Juan. Instituto de Geología y Recursos Minerales, Servicio Geológico Minero Argentino: 47 p. Buenos Aires.

Cardó, R.; Díaz, I.N.; Limarino, C.O.; Litvak, V.D.; Poma, S.; Santamaria, G. 2007. Hoja Geológica 2969-III, Malimán, provincias de San Juan y La Rioja. Instituto de Geología y Recursos Minerales, Servicio Geológico Minero Argentino, Boletín 320: 52 p. Buenos Aires.

Castillo, P.R. 2012. Adakite Petrogenesis. Lithos 134135: 304-316.

Contreras, V.; Damiani, O.; Milana, J.; Bracco, A.; Barrera, M. 1990. Paleógeno y Neógeno de San Juan. In Relatorio Congreso Geológico Argentino, No. 10. Asociación Geológica Argentina: 154-185. San Juan.

Defant, M.J.; Drummond, M.S.1990. Derivation of some modern arc magmas by melting of young subducted lithosphere. Nature 347: 662-665.
Díaz, I.N. 2011. Depósitos piroclásticos en la quebrada de la Despensita al sur del Cordón de Olivares, provincia de San Juan. In Congreso Geológico Argentino, No. 18, Actas CD. Neuquén.

Gómez-Rivarola, L. 2007. Descripción e interpretación de las rocas volcánicas, volcaniclásticas y facies sedimentarias asociadas en la región de Cerro Negro de Iglesia, Precordillera occidental, provincia de San Juan. Trabajo Final de Licenciatura, inédito, 81 p. biblioteca de la Facultad de Ciencias Exactas y Naturales, Universidad de Buenos Aires.

Goss, A.R.; Kay, S.M.; Mpodozis, C. 2013. Andean adakitelike high-Mg andesites on the northern margin of the Chilean-Pampean flat-slab $\left(27-28.5^{\circ} \mathrm{S}\right)$ associated with frontal arc migration and fore-arc subduction erosion. Journal of Petrology 54: 2193-2234.

Hildreth, W.; Moorbath, S. 1988. Crustal contributions to arc magmatism in the Andes of Central Chile. Contributions to Mineralogy and Petrology 98: 455-489.

Jones, R.E.; Kirstein, L.A.; Kasemann, S.A.; Dhuime, B.R., Elliott, T.; Litvak, V.D.; Alonso, R.; Hinton, R.; EIMF 2015. Geodynamic controls on the contamination of Cenozoic arc magmas in the southern Central Andes: Insigths from the $\mathrm{O}$ and $\mathrm{Hf}$ isotopic composition of zircon. Geochimca and Cosmochimica Acta 164: 386-402.

Jones, R.E.; Kirstein, L.A.; Kasemann, S.A.; Litvak, V.D.; Poma, S.; Alonso, R.N.; Hinton, R.; EIMF 2016. The role of changing geodynamics in the progressive contamination of Late Cretaceous to Late Miocene arc magmas in the southern Central Andes. Lithos 262: 169-191.

Jordan,T.E.; Allmendinger, R.W.; Damanti, J.F.; Drake, R.E. 1993a. Chronology of Motion in a Complete Thrust Belt: The Precordillera, 30-31 ${ }^{\circ} \mathrm{S}$, Andes Mountains. The Journal of Geology 101 (2): 135-156.

Jordan, T.E.; Drake, R.E.; Naeser, C.W. 1993b. Estratigrafía del cenozoico medio en la Precordillera a la latitud del Río Jachal, San Juan, Argentina. In Congreso Geológico Argentino, No. 12, y Congreso de Exploración de Hidrocarburos, No. 2, Actas 2:132-141. Mendoza.

Kamvong, T.; Zaw, K.; Meffre, S.; Maas, R.; Stein, H.; Chun-Kit, L. 2014. Adakites in the Truong Son and Loei fold belts, Thailand and Laos: Genesis and implications for geodynamics and metallogeny. Gondwana Research 26 (1): 165-184.

Kay, R. 1978. Aleutian magnesian andesites: melts from subducted Pacific Ocean crust. Journal of Volcanology and Geothermal Research 4: 117-132. 
Kay, S.M.; Abbruzzi, J.M. 1996. Magmatic evidence for Neogene lithospheric evolution of the central Andean (flat-slab) between $30^{\circ} \mathrm{S}$ and $32^{\circ} \mathrm{S}$. Tectonophysics 259: 15-28.

Kay, S.M.; Mpodozis, C. 2002. Magmatism as a probe to the Neogene shallowing of the Nazca plate beneath. Journal of the South American Earth Sciences 15: 39-57.

Kay, S.M.; Mpodozis, C.; Ramos, V.A.; Munizaga, F. 1991. Magma source variations for mid-late Tertiary magmatic rocks associated with a shallowing subduction zone and a thickening crust in the central Andes $\left(28\right.$ to $\left.33^{\circ} \mathrm{S}\right)$. In Andean Magmatism and its Tectonic Setting (Harmon, R.S.; Rapela, C.W.; editors). Geological Society of America Special Papers: 265: 113-137. Boulder.

Kay, S.M.; Orrell, S.; Abbruzzi, J.M. 1996. Zircon and whole rock $\mathrm{Nd}-\mathrm{Pb}$ isotopic evidence for a Grenville age and a Laurentian origin for the basement of the Precordillera in Argentina. The Journal of Geology 104: 637-648.

Kay, S.M.; Mpodozis, C.; Coira, B. 1999. Neogene magmatism, tectonism and mineral deposits of the Central Andes ( $22^{\circ}-23^{\circ} \mathrm{S}$ Latitude). In Geology and Ore Deposits of the Central Andes (Skinner, B.J.; editor). Society of Economic Geologists, Special Publication 7: 27-59. Boulder.

Kay, S.M.; Godoy, E.; Kurtz, A. 2005. Episodic arc migration, crustal thickening, subduction erosion and magmatism in the South-Central Andes. Geological Society of American Bulletin 117: 67-88.

Kay, S.M.; Mpodozis, C.; Gardeweg, M. 2013. Magma sources and tectonic setting of Central Andean andesites (25.5-28 $\mathrm{S})$ related to crustal thickening, forearc subduction erosion and delamination. Geological Society, Special Publications 385: 303-334. London.

LaGatta, A. 2003. Arc magma genesis in the eastern Mexican Volcanic Belt. Ph.D. Thesis (Unpublished), Columbia University: 365 p. New York.

LeMaitre, R.W.; Bateman, P.; Dudek, A.; Keller, J.; Lameyre, J.; Le Bas, M.; Sabine, P.; Schmid, R.; Sorensen, H.; Streckeisen, A. 1989. A Classification of Igneous Rocks and Glossary of Terms: Recommendations of the International Union of Geological Sciences Subcommission on the Systematics of Igneous Rocks. Blackwell: 199 p. Oxford.

Leveratto, M.A. 1976. Edad de intrusivos cenozoicos en la Precordillera de San Juan y su implicancia estratigráfica. Revista de la Asociación Geológica Argentina 31 (1): 53-58.

Litvak, V.D.; Poma, S. 2005. Estratigrafía y facies volcánicas y volcaniclásticas de la Formación Valle del Cura: magmatismo paleógeno en la Cordillera Frontal de San Juan. Revista de la Asociación Geológica Argentina 60 (2): 402-416.

Litvak, V.D.; Poma, S. 2010. Geochemistry of mafic Paleocene volcanic rocks in the Valle del Cura region: implications for the petrogenesis of primary mantlederived melts over the Pampean flat-slab. Journal of South American Earth Sciences 29 (3): 705-716.

Litvak, V.D.; Poma, S. 2014. Petrogenesis of Miocene Volcanic arc rocks over the Chilean-Pampean flat-slab segment of the Central Andes constrained by mineral chemistry. Geologica Acta 12 (2): 151-170.

Litvak, V.D.; Poma, S.; Kay, S.M. 2007. Paleogene and Neogene magmatism in the Valle del Cura region: new perspective on the evolution of the Pampean flat slab, San Juan province, Argentina. Journal of South American Earth Sciences 24 (2-4): 117-137.

Litvak, V.D.; Spagnuolo, M.G.; Folguera, A.; Poma, S.; Jones, R.; Ramos, V.A. 2015. Late Cenozoic calcalkaline volcanism over the Payenia shallow subduction zone, South-Central Andean back arc (3430'-37º S), Argentina. Journal of South American Earth Sciences 64 (2): 365-380.

Llambías, E.J.; Shaw, S.; Sato, A.M. 1990. Lower Miocene plutons in the Eastern Cordillera Frontal of San Juan (2975'S 69³0'W). In Congreso Geológico Argentino No. 11, Actas 1:83-86. San Juan.

Maksaev, V.; Moscoso, R.; Mpodozis, C.; Nasi, C. 1984. Las unidades volcánicas y plutónicas del Cenozoico superior en la alta cordillera del Norte Chico $\left(29^{\circ}-31^{\circ} \mathrm{S}\right)$ : geología, alteración hidrotermal y mineralización. Revista Geológica de Chile 21: 11-51. doi: 10.5027/andgeoV11n1-a02.

Martin, H.; Smithies, R.H.; Rapp, R.; Moyen, J.-F.; Champion, D. 2005. An overview of adakite, tonalitetrondhjemite-granodiorite (TTG), and sanukitoid: relationships and some implications for crustal evolution. Lithos 79 (1-2): 1-24.

Montero-López, M.C.; Hongn, F.; Seggiaro, R.; Brod, J.A.; Marrett, R. 2010. Estratigrafía y geoquímica del volcanismo de composición intermedia (Mioceno Superior-Plioceno) en el extremo oriental de la cordillera de San Buenaventura (Puna Austral). Revista de la Asociación Geológica Argentina 67 (1): 112-129.

Mori, L.; Gómez-Tuena, A.; Cai, Y.; Goldstein, S.L. 2007. Effects of prolonged flat subduction on the Miocene magmatic record of the central Trans-Mexican Volcanic Belt. Chemical Geology 244: 452-473.

Moyen, J. F. 2009. High Sr/Y and La/Yb ratios: The meaning of the "adakitic signature" Lithos 112 (3-4): 556-574. 
Nakamura, N. 1974. Determination of REE, Ba, Fe, Mg, $\mathrm{Na}$, and $\mathrm{K}$ in carbonaceous and ordinary chondrites. Geochimica et Cosmochimica Acta 38 (5): 757-775.

Pearce, J.A. 1983. Role of the sub-continental lithosphere in magma genesis at active continental margins. In Continental basalts and mantle xenoliths (Hawkesworth, C.J.; Norry, M.J.; editors). Shiva Publications: 230249. Nantwich.

Pilger, R.H. 1981. Plate reconstructions, aseismic ridges, and low angle subduction beneath the Andes. Geological Society of America Bulletin 92 (7): 448-456.

Pilger, R.H. 1984. Cenozoic plate kinematics, subduction and magmatism: South American Andes. Journal of Geological Society London 141: 793-802.

Poma, S.; Ramos, A.; Litvak, V.D.; Quenardelle, S.; Maisonnave, B. 2014. Tertiary volcanism from Iglesia Valley Basin, San Juan province, Argentina. In Congreso Geológico Argentino, No. 19, Actas: S24-2-2. Córdoba.

Ramos, V.A. 1988. The tectonics of the Central Andes $\left(30^{\circ}-33^{\circ} \mathrm{S}\right.$ latitude). In Processes in Continental Lithospheric Deformation (Clark, S.; Burchfiel, D.; Suppe, D.; editors). Geological Society of America, Special Paper 218: 31-54.

Ramos, V.A.; Folguera, A. 2009. Andean flat-slab subduction through time. Geological Society of London, Special Publications 327: 31-54.

Ramos, V.; Jordan, T.E.; Allmendinger, R.; Kay, S.; Cortés, J.M.; Palma, M.A. 1984. Chilenia: Un terreno alóctono en la evolución paleozoica de los Andes Centrales. In Congreso Geológico Argentino, No. 9, Actas 2: 84-106. San Carlos de Bariloche.

Ramos, V.A.; Page, R.; Kay, S.M.; Lapido, O.; Delpino, D. 1987. Geología de la región del volcán Tórtolas, Valle del Cura, provincia de San Juan. In Congreso Geológico Argentino, No. 10, Actas 4: 260-263. Tucumán.

Ramos, V.A.; Kay, S.M.; Page, R.; Munizaga, F. 1989. La Ignimbrita Vacas Heladas y el cese del volcanismo en el valle del Cura, provincia de San Juan. Revista de la Asociación Geológica Argentina 44 (1): 336-352.

Ramos, V.A.; Zapata, T.; Cristallini, E.; Introcaso, A. 2004. The Andean thrust system-latitudinal variations in structural styles and orogenic shortening. In Thrust tectonics and hydrocarbon systems (McClay, K.R.; editor). American Association of Petroleum Geologists, Memoir 82: 30-50.
Ré, G.; Barredo, S. 1993. Estudio magneto estratigráfico y tasa de sedimentación del Grupo Iglesia en sus afloramientos aledaños a la localidad de Angualasto (Provincia de San Juan). In Congreso Geológico Argentino, No. 12, Actas 2: 148-155. Mendoza.

Rollinson, H.R. 1993. Using Geochemical Data: Evaluation, Presentation, Interpretation. Longman Scientific and Technical: 352 p. London.

Sillittoe, R. 1977. Permo-Carbonifeous, Upper Cretaceous and Miocene Porphyry Cooper-Type Mineralization in the Argentinian Andes. Economic Geology 72 (1): 99-103.

Stern, C.R. 1991. Role of subduction erosion in the generation of the Andean magmas. Geology 19: 78-81.

Stern, C.R. 2011. Subduction erosion: Rates, mechanisms, and its role in arc magmatism and the evolution of the continental crust and mantle. Gondwana Research 20: 284-308.

Walker, G.P.L.; Heming, R.F.; Wilson, C.J.N. 1980. Lowaspectratio ignimbrites. Nature 283: 286-287.

Weidmann, R.; Cardinal, A.; Simon, W. 1985. Propuesta de ordenamiento de la nomenclatura estratigráfica de las sedimentitas terciarias de la Precordillera sanjuanina. In Jornadas sobre Geología de Precordillera, No. 1, Actas: 342-347. San Juan.

Wetten, C. 1975. Estudio geológico-económico de un yacimiento de diatomita y análisis de mercado. In Congreso Ibero-Americano de Geología Económica, No. 2, Actas 5: 513-529. Buenos Aires.

Wetten, A.F. 1995. Distrito minero Tocota, San Juan, Argentina: aporte al conocimiento de su geología y mineralización. In Congreso Nacional de Geología Económica y Simposio de Metalogenia Andina, No. 5, Actas: 60-68. San Juan.

Wetten, A.F. 2005. Andesita Cerro Bola: Nueva unidad vinculada al magmatismo mioceno de la Cordillera de Olivares, San Juan, Argentina (30³5'S; 69³0'O). Revista de la Asociación Geológica Argentina 60 (1): 3-8.

Yáñez, G.A.; Ranero, C.R.; von Huene, R.; Díaz, J. 2001. Magnetic anomaly interpretation across the southern central Andes $\left(32^{\circ}-34^{\circ} \mathrm{S}\right)$ : the role of the Juan Fernández Ridge in the late Tertiary evolution of the margin. Journal of Geophysical Research 106: 6325-6345. 
APPENDIX. GEOCHEMICAL RESULTS OF MIOCENE ARC-RELATED ROCKS (LOMAS DEL CAMPANARIO UNIT) FROM IGLESIA VALLEY, WESTERN PRECORDILLERA.

\begin{tabular}{|c|c|c|c|c|c|c|c|c|c|}
\hline \multirow{4}{*}{$\begin{array}{c}\text { Area } \\
\text { Location } \\
\text { Sample } \\
\text { Petrographic type }\end{array}$} & \multicolumn{7}{|c|}{ Tocota } & \multicolumn{2}{|c|}{ Rodeo } \\
\hline & $\begin{array}{c}\text { Qda. } \\
\text { Morteritos }\end{array}$ & $\begin{array}{c}\text { Qda. } \\
\text { Morteritos }\end{array}$ & $\begin{array}{c}\text { Qda. } \\
\text { Morteritos }\end{array}$ & $\begin{array}{c}\text { Qda. } \\
\text { Aguaditas }\end{array}$ & $\begin{array}{c}\text { Qda. } \\
\text { Aguaditas }\end{array}$ & $\begin{array}{c}\text { Qda. } \\
\text { Aguaditas }\end{array}$ & $\begin{array}{c}\text { Qda. } \\
\text { Aguaditas }\end{array}$ & $\begin{array}{c}\text { Cuesta del } \\
\text { Viento }\end{array}$ & $\begin{array}{c}\text { Cuesta del } \\
\text { Viento }\end{array}$ \\
\hline & TOC25 & TOC09 & TOC06 & TOC08 & PI34 & TOC24A & TOC24B & 1956 & CO1 \\
\hline & \multicolumn{9}{|c|}{ Crystal-vitreous tuffs } \\
\hline $\mathrm{SiO}_{2} \mathrm{wt} \%$ & 62.97 & 61.42 & 63.1 & 62.47 & 62.62 & 65.73 & 65.65 & 53.22 & 56.02 \\
\hline $\mathrm{TiO}_{2} \mathrm{wt} \%$ & 0.624 & 0.65 & 0.473 & 0.467 & 0.612 & 0.403 & 0.415 & 0.438 & 0.563 \\
\hline $\mathrm{Al}_{2} \mathrm{O}_{3} \mathrm{wt} \%$ & 16.37 & 16.47 & 18.56 & 18.29 & 16.53 & 16.46 & 16.07 & 16.66 & 16.91 \\
\hline $\mathrm{Fe}_{2} \mathrm{O}_{3}(\mathrm{t}) \mathrm{wt} \%$ & 4.51 & 4.46 & 3.25 & 3.14 & 4.27 & 3.12 & 3.16 & 2.86 & 4.04 \\
\hline $\mathrm{MnO} w \mathrm{w} \%$ & 0.079 & 0.077 & 0.05 & 0.051 & 0.075 & 0.069 & 0.067 & 0.048 & 0.058 \\
\hline $\mathrm{MgO} w \mathrm{wt} \%$ & 1.66 & 2.06 & 0.87 & 0.9 & 1.7 & 0.89 & 0.88 & 1.17 & 1.38 \\
\hline $\mathrm{CaO} w \mathrm{w} \%$ & 4.2 & 4.41 & 4.54 & 4.48 & 4.46 & 3.78 & 3.58 & 4.94 & 4.81 \\
\hline $\mathrm{Na}_{2} \mathrm{O} w t \%$ & 4.17 & 4.02 & 5.28 & 5.16 & 4.31 & 4.2 & 4.01 & 10.1 & 7.65 \\
\hline $\mathrm{K}_{2} \mathrm{O} w \mathrm{t} \%$ & 2.65 & 2.54 & 2.00 & 1.83 & 2.36 & 2.56 & 2.68 & 1.08 & 1.11 \\
\hline $\mathrm{P} 2 \mathrm{O} 5 \mathrm{wt} \%$ & 0.26 & 0.28 & 0.2 & 0.19 & 0.27 & 0.22 & 0.21 & 0.18 & 0.2 \\
\hline LOI wt $\%$ & 2.08 & 2.82 & 2.19 & 2.22 & 2.5 & 2.97 & 3.24 & 9.80 & 7.99 \\
\hline Total & 99.55 & 99.2 & 100.5 & 99.21 & 99.69 & 100.4 & 99.96 & 100.5 & 100.7 \\
\hline $\mathrm{FeO}(\mathrm{t})^{*} \mathrm{wt} \%$ & 4.06 & 4.01 & 2.92 & 2.83 & 3.84 & 2.8 . & 2.84 & 2.57 & 3.64 \\
\hline La ppm & 25.1 & 25.7 & 17.8 & 17.3 & 25.8 & 17 & 20.8 & 13.8 & 17.6 \\
\hline Ce ppm & 49.6 & 52.3 & 34.5 & 34.5 & 50.6 & 36.2 & 41.3 & 30 & 37.9 \\
\hline Pr ppm & 6.04 & 6.06 & 4.09 & 3.96 & 5.95 & 4.41 & 4.89 & 3.79 & 4.52 \\
\hline $\mathrm{Nd}$ ppm & 22 & 21.6 & 14.8 & 14.1 & 21.2 & 16.3 & 18.1 & 14.7 & 19 \\
\hline Sm ppm & 4.69 & 4.69 & 3.18 & 2.99 & 4.46 & 3.55 & 3.98 & 3.1 & 3.69 \\
\hline Eu ppm & 1.46 & 1.4 & 1.27 & 1.17 & 1.38 & 1.16 & 1.29 & 1.26 & 1.17 \\
\hline Gd ppm & 3.77 & 3.77 & 2.34 & 2.26 & 3.54 & 2.66 & 3.14 & 2.4 & 2.63 \\
\hline $\mathrm{Tb}$ ppm & 0.48 & 0.47 & 0.29 & 0.29 & 0.45 & 0.38 & 0.42 & 0.3 & 0.38 \\
\hline Dy ppm & 2.34 & 2.32 & 1.47 & 1.49 & 2.2 & 2.02 & 2.18 & 1.7 & 1.82 \\
\hline Ho ppm & 0.42 & 0.43 & 0.26 & 0.27 & 0.4 & 0.37 & 0.4 & 0.3 & 0.31 \\
\hline Er ppm & 1.13 & 1.23 & 0.73 & 0.72 & 1.11 & 1.04 & 1.09 & 0.8 & 0.89 \\
\hline
\end{tabular}




\begin{tabular}{|c|c|c|c|c|c|c|c|c|c|}
\hline \multirow{2}{*}{$\begin{array}{c}\text { Area } \\
\text { Location }\end{array}$} & \multicolumn{7}{|c|}{ Tocota } & \multicolumn{2}{|c|}{ Rodeo } \\
\hline & $\begin{array}{c}\text { Qda. } \\
\text { Morteritos }\end{array}$ & $\begin{array}{c}\text { Qda. } \\
\text { Morteritos }\end{array}$ & $\begin{array}{c}\text { Qda. } \\
\text { Morteritos }\end{array}$ & $\begin{array}{c}\text { Qda. } \\
\text { Aguaditas }\end{array}$ & $\begin{array}{c}\text { Qda. } \\
\text { Aguaditas }\end{array}$ & $\begin{array}{c}\text { Qda. } \\
\text { Aguaditas }\end{array}$ & $\begin{array}{c}\text { Qda. } \\
\text { Aguaditas }\end{array}$ & $\begin{array}{c}\text { Cuesta del } \\
\text { Viento }\end{array}$ & $\begin{array}{c}\text { Cuesta del } \\
\text { Viento }\end{array}$ \\
\hline Sample & TOC25 & TOC09 & TOC06 & TOC08 & PI34 & TOC24A & TOC24B & 1956 & CO1 \\
\hline Petrographic type & \multicolumn{9}{|c|}{ Crystal-vitreous tuffs } \\
\hline Tm ppm & 0.156 & 0.171 & 0.101 & 0.103 & 0.154 & 0.147 & 0.158 & 0.12 & 0.127 \\
\hline $\mathrm{Yb}$ ppm & 0.98 & 1.04 & 0.66 & 0.65 & 0.98 & 0.95 & 1.02 & 0.8 & 0.78 \\
\hline Lu ppm & 0.144 & 0.16 & 0.112 & 0.103 & 0.156 & 0.142 & 0.156 & 0.12 & 0.138 \\
\hline Y ppm & 12 & 12.5 & 8.2 & 7.6 & 12.2 & 11.3 & 12.3 & 8 & 9.3 \\
\hline $\mathrm{Sr}$ ppm & 846 & 862 & 1,197 & 1,173 & 866 & 879 & 820 & 1,263 & 1,268 \\
\hline $\mathrm{Ba}$ ppm & 723 & 738 & 625 & 624 & 725 & 1,352 & 932 & 420 & 367 \\
\hline Cs ppm & 1.3 & 1.1 & 0.9 & 0.8 & 1.1 & 1 & 1.2 & 0.7 & 0.8 \\
\hline $\mathrm{U}$ ppm & 0.8 & 0.78 & 0.61 & 0.6 & 0.73 & 0.7 & 0.8 & 0.4 & 0.64 \\
\hline Th ppm & 2.72 & 3.19 & 1.8 & 1.8 & 2.77 & 1.71 & 2.29 & 1.4 & 1.85 \\
\hline Hf ppm & 4.6 & 5.1 & 3.7 & 3.6 & 4.8 & 4.1 & 5 & 2.8 & 3.3 \\
\hline Ta ppm & 0.62 & 0.63 & 0.48 & 0.46 & 0.63 & 0.58 & 0.71 & 0.3 & 0.85 \\
\hline $\mathrm{Rb}$ ppm & 43 & 42 & 28 & 26 & 38 & 35 & 40 & 18 & 20 \\
\hline $\mathrm{Nb}$ ppm & 8.8 & 8.9 & 7 & 6.6 & 8.9 & 8.2 & 9.2 & 5 & 7.5 \\
\hline $\mathrm{Zr} \mathrm{ppm}$ & 172 & 188 & 143 & 133 & 182 & 154 & 187 & 111 & 150 \\
\hline $\mathrm{Sr} / \mathrm{Y}$ & 70.5 & 69.0 & 146.0 & 154.3 & 71.0 & 77.8 & 66.7 & 157.9 & 136.3 \\
\hline $\mathrm{Ba} / \mathrm{La}$ & 28.8 & 28.7 & 35.1 & 36.1 & 28.1 & 79.5 & 44.8 & 30.4 & 20.9 \\
\hline $\mathrm{La} / \mathrm{Sm}$ & 5.4 & 5.5 & 5.6 & 5.8 & 5.8 & 4.8 & 5.2 & 4.5 & 4.8 \\
\hline $\mathrm{La} / \mathrm{Yb}$ & 25.6 & 24.7 & 27.0 & 26.6 & 26.3 & 17.9 & 20.4 & 17.3 & 22.6 \\
\hline $\mathrm{Sm} / \mathrm{Yb}$ & 4.8 & 4.5 & 4.8 & 4.6 & 4.6 & 3.7 & 3.9 & 3.9 & 4.7 \\
\hline $\mathrm{Ba} / \mathrm{Ta}$ & 1,166 & 1,171 & 1,302 & 1,357 & 1,151 & 2,331 & 1,313 & 1,400 & 432 \\
\hline $\mathrm{La} / \mathrm{Ta}$ & 40.5 & 40.8 & 37.1 & 37.6 & 41.0 & 29.3 & 29.3 & 46.0 & 20.7 \\
\hline $\mathrm{Gd} / \mathrm{Yb}$ & 3.8 & 3.6 & 3.5 & 3.5 & 3.6 & 2.8 & 3.1 & 3.0 & 3.372 \\
\hline $\mathrm{Rb} / \mathrm{Nb}$ & 4.9 & 4.7 & 4.0 & 3.9 & 4.3 & 4.3 & 4.3 & 3.6 & 2.67 \\
\hline $\mathrm{Sr} / \mathrm{Nb}$ & 96.1 & 96.9 & 171.0 & 177.7 & 97.3 & 107.2 & 89.1 & 252.6 & 169.06 \\
\hline Coordinates & $30^{\circ} 44^{\prime} 05^{\prime \prime} \mathrm{S}$ & $30^{\circ} 44^{\prime} 38^{\prime \prime} \mathrm{S}$ & $30^{\circ} 45^{\prime} 8^{\prime \prime} \mathrm{S}$ & $30^{\circ} 45^{\prime} 11^{\prime \prime S}$ & $30^{\circ} 42^{\prime} 33^{\prime \prime} \mathrm{S}$ & $30^{\circ} 42^{\prime} 08^{\prime \prime} \mathrm{S}$ & $30^{\circ} 42^{\prime} 08^{\prime \prime} \mathrm{S}$ & $30^{\circ} 45^{\prime} 11^{\prime \prime S}$ & $30^{\circ} 12^{\prime} 22^{\prime \prime} \mathrm{S}$ \\
\hline & $69^{\circ} 30^{\prime} 42^{\prime \prime} \mathrm{S}$ & $69^{\circ} 30^{\prime} 38^{\prime \prime} \mathrm{S}$ & $69^{\circ} 30^{\prime} 18^{\prime \prime S}$ & $69^{\circ} 30^{\prime} 21^{\prime \prime S}$ & $69^{\circ} 27^{\prime} 12^{\prime \prime S}$ & $69^{\circ} 30^{\prime} 23^{\prime \prime S}$ & $69^{\circ} 30^{\prime} 23^{\prime \prime S}$ & $69^{\circ} 30^{\prime} 21^{\prime \prime S}$ & $69^{\circ} 04^{\prime} 06^{\prime \prime} \mathrm{S}$ \\
\hline
\end{tabular}


Appendix continued.

\begin{tabular}{|c|c|c|c|c|c|c|c|c|c|c|c|c|}
\hline \multirow{2}{*}{$\begin{array}{c}\text { Area } \\
\text { Location }\end{array}$} & \multicolumn{8}{|c|}{ Tocota } & \multicolumn{4}{|c|}{ Chita } \\
\hline & $\begin{array}{c}\text { Qda. } \\
\text { Aguaditas }\end{array}$ & $\begin{array}{c}\text { Qda. } \\
\text { Aguaditas }\end{array}$ & $\begin{array}{c}\text { Qda. } \\
\text { Aguaditas }\end{array}$ & $\begin{array}{l}\text { Qda. } \\
\text { Tocota }\end{array}$ & Co. Bola & Co. Bola & Co. Bola & Co. Bola & $\begin{array}{l}\text { Qda. } \\
\text { Chita }\end{array}$ & $\begin{array}{l}\text { Qda. } \\
\text { Chita }\end{array}$ & $\begin{array}{l}\text { Qda. } \\
\text { Chita }\end{array}$ & $\begin{array}{l}\text { Qda. } \\
\text { Chita }\end{array}$ \\
\hline Sample & TOC21 & TOC23A & TOC23A & TOC01 & TOC14 & TOC15 & TOC16 & TOC17 & TOC26 & TOC27B & TOC27D & TOC30 \\
\hline Petrographic type & Andesite & Andesite & Andesite & Andesita & Dacite & Dacite & Dacite & Dacite & Dacita & Dacite & Dacite & Andesite \\
\hline $\mathrm{SiO}_{2} \mathrm{wt} \%$ & 51.95 & 51.08 & 58.68 & 62.74 & 63.03 & 63.94 & 63.98 & 63.41 & 67.57 & 68.92 & 66.24 & 63.28 \\
\hline $\mathrm{TiO}_{2} \mathrm{wt} \%$ & 1.139 & 1.073 & 1.102 & 0.834 & 0.697 & 0.611 & 0.601 & 0.664 & 0.416 & 0.358 & 0.363 & 0.666 \\
\hline $\mathrm{Al}_{2} \mathrm{O}_{3} \mathrm{wt} \%$ & 15.86 & 15.21 & 16.56 & 16.92 & 17.39 & 16.9 & 17.01 & 17.61 & 15.44 & 14.91 & 15.22 & 16.92 \\
\hline $\mathrm{Fe}_{2} \mathrm{O}_{3}(\mathrm{t}) \mathrm{wt} \%$ & 8.28 & 10.46 & 7.25 & 6.69 & 4.65 & 4.34 & 4.38 & 4.56 & 2.91 & 2.68 & 2.85 & 4.57 \\
\hline $\mathrm{MnO} w \mathrm{w} \%$ & 0.1 & 0.128 & 0.195 & 0.094 & 0.079 & 0.052 & 0.062 & 0.078 & 0.051 & 0.044 & 0.046 & 0.066 \\
\hline $\mathrm{MgO}$ wt $\%$ & 6.64 & 6.59 & 2.69 & 2.23 & 1.4 & 1.4 & 1.4 & 1.38 & 1.03 & 0.82 & 0.86 & 1.82 \\
\hline $\mathrm{CaO} w \mathrm{t} \%$ & 7.11 & 5.51 & 6.15 & 0.98 & 4.31 & 4.06 & 3.8 & 4.38 & 3.21 & 2.23 & 2.52 & 4.64 \\
\hline $\mathrm{Na}_{2} \mathrm{O} w t \%$ & 3.7 & 3.4 & 3.46 & 1.33 & 5.39 & 5.5 & 5.34 & 5.46 & 4.94 & 3.98 & 3.93 & 5.06 \\
\hline $\mathrm{K}_{2} \mathrm{O} w \mathrm{t} \%$ & 2.33 & 1.65 & 2.37 & 3.78 & 2.17 & 2.11 & 2.18 & 2.21 & 2.85 & 3.78 & 3.6 & 2.03 \\
\hline $\mathrm{P}_{2} \mathrm{O}_{5} \mathrm{wt} \%$ & 0.33 & 0.3 & 0.36 & 0.13 & 0.27 & 0.32 & 0.23 & 0.28 & 0.18 & 0.16 & 0.17 & 0.26 \\
\hline LOI wt $\%$ & 2.64 & 3.32 & 1.21 & 3.14 & 0.65 & 0.91 & 0.96 & 0.73 & 1.72 & 2.92 & 3.18 & 0.58 \\
\hline Total & 100.1 & 98.71 & 100.00 & 98.89 & 100.00 & 100.1 & 99.94 & 100.7 & 100.3 & 100.8 & 98.98 & 99.9 \\
\hline $\mathrm{FeO}(\mathrm{t}) * \mathrm{wt} \%$ & 7.45 & 9.41 & 6.52 & 6.02 & 4.18 & 3.91 & 3.94 & 4.10 & 2.62 & 2.41 & 2.56 & 4.11 \\
\hline La ppm & 16.6 & 21.5 & 38.6 & 41.8 & 22.7 & 23.1 & 22.3 & 23.9 & 20.9 & 15.6 & 17.7 & 23.5 \\
\hline Ce ppm & 39 & 45.4 & 82.6 & 88 & 48.1 & 46 & 46.4 & 49.5 & 42.3 & 33.2 & 36.8 & 46.6 \\
\hline Pr ppm & 4.7 & 5.21 & 9.03 & 9.37 & 5.31 & 5.21 & 5.15 & 5.42 & 4.63 & 3.72 & 4.07 & 5.53 \\
\hline $\mathrm{Nd}$ ppm & 19.6 & 19.9 & 32.2 & 33.3 & 18.6 & 18.3 & 17.7 & 18.7 & 15.5 & 12.9 & 14.3 & 20.1 \\
\hline Sm ppm & 5.01 & 4.64 & 6.99 & 7.25 & 3.9 & 3.67 & 3.66 & 3.98 & 3.23 & 2.71 & 2.9 & 4.33 \\
\hline Eu ppm & 1.77 & 1.43 & 2.06 & 1.55 & 1.34 & 1.27 & 1.22 & 1.35 & 0.972 & 0.844 & 0.915 & 1.4 \\
\hline Gd ppm & 4.4 & 4.03 & 5.63 & 6.4 & 2.92 & 2.79 & 2.67 & 2.83 & 2.21 & 1.88 & 1.99 & 3.29 \\
\hline $\mathrm{Tb}$ ppm & 0.65 & 0.63 & 0.82 & 1.03 & 0.41 & 0.4 & 0.37 & 0.4 & 0.3 & 0.26 & 0.27 & 0.41 \\
\hline Dy ppm & 3.63 & 3.58 & 4.63 & 6.2 & 2.09 & 2.06 & 1.94 & 2.07 & 1.59 & 1.35 & 1.42 & 2.05 \\
\hline Ho ppm & 0.71 & 0.71 & 0.92 & 1.26 & 0.38 & 0.38 & 0.37 & 0.38 & 0.3 & 0.25 & 0.26 & 0.36 \\
\hline Er ppm & 2 & 2.08 & 2.74 & 3.77 & 1.05 & 1.06 & 1.04 & 1.06 & 0.85 & 0.7 & 0.74 & 0.98 \\
\hline Tm ppm & 0.278 & 0.295 & 0.393 & 0.552 & 0.148 & 0.146 & 0.149 & 0.151 & 0.121 & 0.102 & 0.105 & 0.137 \\
\hline
\end{tabular}




\begin{tabular}{|c|c|c|c|c|c|c|c|c|c|c|c|c|}
\hline \multirow{2}{*}{$\begin{array}{c}\text { Area } \\
\text { Location }\end{array}$} & \multicolumn{8}{|c|}{ Tocota } & \multicolumn{4}{|c|}{ Chita } \\
\hline & $\begin{array}{c}\text { Qda. } \\
\text { Aguaditas }\end{array}$ & $\begin{array}{c}\text { Qda. } \\
\text { Aguaditas }\end{array}$ & $\begin{array}{c}\text { Qda. } \\
\text { Aguaditas }\end{array}$ & $\begin{array}{l}\text { Qda. } \\
\text { Tocota }\end{array}$ & Co. Bola & Co. Bola & Co. Bola & Co. Bola & $\begin{array}{l}\text { Qda. } \\
\text { Chita }\end{array}$ & $\begin{array}{l}\text { Qda. } \\
\text { Chita }\end{array}$ & $\begin{array}{l}\text { Qda. } \\
\text { Chita }\end{array}$ & $\begin{array}{l}\text { Qda. } \\
\text { Chita }\end{array}$ \\
\hline Sample & TOC21 & TOC23A & TOC23A & TOC01 & TOC14 & TOC15 & TOC16 & TOC17 & TOC26 & TOC27B & TOC27D & TOC30 \\
\hline Petrographic type & Andesite & Andesite & Andesite & Andesita & Dacite & Dacite & Dacite & Dacite & Dacita & Dacite & Dacite & Andesite \\
\hline $\mathrm{Yb}$ ppm & 1.65 & 1.75 & 2.35 & 3.29 & 0.93 & 0.93 & 0.92 & 0.93 & 0.75 & 0.66 & 0.65 & 0.89 \\
\hline Lu ppm & 0.238 & 0.259 & 0.35 & 0.5 & 0.135 & 0.137 & 0.141 & 0.138 & 0.124 & 0.103 & 0.104 & 0.137 \\
\hline Y ppm & 19.8 & 20 & 26.1 & 36.6 & 11.3 & 12 & 10.8 & 11.4 & 9.2 & 7.3 & 8 & 11 \\
\hline Sr ppm & 432 & 336 & 672 & 111 & 998 & 1,051 & 1,010 & 1,016 & 792 & 1,029 & 977 & 917 \\
\hline Ba ppm & 480 & 364 & 1,049 & 734 & 848 & 957 & 860 & 853 & 777 & 1,013 & 886 & 765 \\
\hline Cs ppm & 11.8 & 8 & 10 & 15.7 & 0.4 & 0.5 & 0.5 & 0.4 & 1.8 & 1.7 & 1.8 & 1 \\
\hline U ppm & 2.36 & 2.62 & 1.77 & 2.37 & 0.81 & 0.68 & 0.63 & 0.63 & 1.33 & 1.04 & 1.2 & 0.69 \\
\hline Th ppm & 8.01 & 9.01 & 8.33 & 12.7 & 2.04 & 1.77 & 1.87 & 1.91 & 3.36 & 2.18 & 2.36 & 2.71 \\
\hline Hf ppm & 3.4 & 3.5 & 5.5 & 4.8 & 5.1 & 5.1 & 5 & 5.1 & 3.9 & 3.7 & 3.9 & 4.6 \\
\hline Ta ppm & 0.6 & 0.63 & 0.91 & 1.25 & 0.58 & 0.46 & 0.47 & 0.59 & 0.47 & 0.46 & 0.49 & 0.6 \\
\hline $\mathrm{Rb}$ ppm & 143 & 94 & 94 & 179 & 31 & 30 & 31 & 32 & 51 & 80 & 77 & 36 \\
\hline $\mathrm{Nb}$ ppm & 7.3 & 7.4 & 13.1 & 15.1 & 10.2 & 7.8 & 8.1 & 9.9 & 7 & 6.7 & 7 & 8.6 \\
\hline $\mathrm{Zr} \mathrm{ppm}$ & 120 & 128 & 212 & 166 & 225 & 209 & 206 & 220 & 136 & 133 & 136 & 169 \\
\hline $\mathrm{Sr} / \mathrm{Y}$ & 21.8 & 16.8 & 25.7 & 3.0 & 88.3 & 87.6 & 93.5 & 89.1 & 86.1 & 141.0 & 122.1 & 83.4 \\
\hline $\mathrm{Ba} / \mathrm{La}$ & 28.9 & 16.9 & 27.2 & 17.6 & 37.4 & 41.4 & 38.6 & 35.7 & 37.2 & 64.9 & 50.1 & 32.6 \\
\hline $\mathrm{La} / \mathrm{Sm}$ & 3.3 & 4.6 & 5.5 & 5.8 & 5.8 & 6.3 & 6.1 & 6.0 & 6.5 & 5.8 & 6.1 & 5.4 \\
\hline $\mathrm{La} / \mathrm{Yb}$ & 10.1 & 12.3 & 16.4 & 12.7 & 24.4 & 24.8 & 24.2 & 25.7 & 27.9 & 23.6 & 27.2 & 26.4 \\
\hline $\mathrm{Sm} / \mathrm{Yb}$ & 3.0 & 2.7 & 3.0 & 2.2 & 4.2 & 3.9 & 4.0 & 4.3 & 4.3 & 4.1 & 4.5 & 4.9 \\
\hline $\mathrm{Ba} / \mathrm{Ta}$ & 800 & 578 & 1,153 & 587 & 1,462 & 2,080 & 1,830 & 1,446 & 1,653 & 2,202 & 1,808 & 1,275 \\
\hline $\mathrm{La} / \mathrm{Ta}$ & 27.7 & 34.1 & 42.4 & 33.4 & 39.1 & 50.2 & 47.4 & 40.5 & 44.5 & 33.9 & 36.1 & 39.2 \\
\hline $\mathrm{Gd} / \mathrm{Yb}$ & 2.7 & 2.3 & 2.4 & 1.945 & 3.1 & 3.0 & 2.9 & 3.0 & 2.9 & 2.85 & 3.06 & 3.7 \\
\hline $\mathrm{Rb} / \mathrm{Nb}$ & 19.6 & 12.7 & 7.2 & 11.854 & 3.0 & 3.8 & 3.8 & 3.2 & 7.3 & 11.94 & 11 & 4.2 \\
\hline $\mathrm{Sr} / \mathrm{Nb}$ & 59.2 & 45.4 & 51.3 & 7.35 & 97.8 & 134.7 & 124.7 & 102.6 & 113.1 & 153.58 & 139.6 & 106.6 \\
\hline \multirow[t]{2}{*}{ Coordinates } & $30^{\circ} 41^{\prime} 57^{\prime \prime} \mathrm{S}$ & $30^{\circ} 45^{\prime} 11^{\prime \prime} \mathrm{S}$ & $30^{\circ} 41^{\prime} 49^{\prime \prime S}$ & $30^{\circ} 39^{\prime} 55^{\prime \prime} \mathrm{S}$ & $30^{\circ} 39^{\prime} 20^{\prime \prime} \mathrm{S}$ & $30^{\circ} 39^{\prime} 17^{\prime \prime} \mathrm{S}$ & $30^{\circ} 39^{\prime} 15^{\prime \prime} \mathrm{S}$ & $30^{\circ} 39^{\prime} 33^{\prime \prime} \mathrm{S}$ & $30^{\circ} 32^{\prime} 56^{\prime \prime} \mathrm{S}$ & $30^{\circ} 32^{\prime} 51^{\prime \prime S}$ & $30^{\circ} 32^{\prime} 51^{\prime \prime S}$ & $30^{\circ} 33^{\prime} 05^{\prime \prime} \mathrm{S}$ \\
\hline & $69^{\circ} 30^{\prime} 33^{\prime \prime S}$ & $69^{\circ} 30^{\prime} 21^{\prime \prime S}$ & $69^{\circ} 29^{\prime} 59^{\prime \prime S}$ & $69^{\circ} 27^{\prime} 41^{\prime \prime S}$ & $69^{\circ} 31^{\prime} 24^{\prime \prime} \mathrm{S}$ & $69^{\circ} 31^{\prime} 25^{\prime \prime S} \mathrm{~S}$ & $69^{\circ} 31^{\prime} 29^{\prime \prime S} \mathrm{~S}$ & $69^{\circ} 31^{\prime} 16^{\prime \prime S}$ & $69^{\circ} 33^{\prime} 02^{\prime \prime S}$ & $69^{\circ} 32^{\prime} 12^{\prime \prime S}$ & $69^{\circ} 32^{\prime} 12^{\prime \prime} \mathrm{S}$ & $69^{\circ} 30^{\prime} 08^{\prime \prime} \mathrm{S}$ \\
\hline
\end{tabular}




\begin{tabular}{|c|c|c|c|c|c|c|c|c|c|c|c|c|}
\hline \multirow{2}{*}{$\begin{array}{c}\text { Area } \\
\text { Location }\end{array}$} & \multicolumn{2}{|c|}{ Tocota } & \multirow[b]{2}{*}{$\begin{array}{l}\text { Co. Puntas } \\
\text { Negras }\end{array}$} & \multirow[b]{2}{*}{ Co. Negro } & \multirow[b]{2}{*}{ Co. Negro } & \multicolumn{3}{|c|}{ Cerro Negro } & \multirow[b]{2}{*}{ Co. Negro } & \multirow[b]{2}{*}{ Co. Negro } & \multirow[b]{2}{*}{ Co. Negro } & \multirow[b]{2}{*}{ Co. Negro } \\
\hline & $\begin{array}{l}\text { Divisadero } \\
\text { Sur }\end{array}$ & $\begin{array}{c}\text { Co. Divi- } \\
\text { sadero }\end{array}$ & & & & Co. Negro & Co. Negro & Co. Negro & & & & \\
\hline Sample & TOC31 & TOC10 & CN201 & CN2 & CN4 & CN6 & CN15 & CN17 & CN18 & $\mathrm{CN} 23$ & CN27 & CNH31 \\
\hline Petrographic type & Andesite & Andesite & Andesite & Andesite & Andesite & Dacite & Dacite & Dacite & Dacite & Andesite & Andesite & Dacite \\
\hline $\mathrm{SiO}_{2} \mathrm{wt} \%$ & 59.98 & 62.61 & 61.46 & 61.71 & 61.19 & 69.92 & 67.78 & 64.02 & 63.59 & 62.03 & 61.99 & 64.63 \\
\hline $\mathrm{TiO}_{2} \mathrm{wt} \%$ & 0.738 & 0.627 & 0.528 & 0.617 & 0.608 & 0.416 & 0.488 & 0.617 & 0.712 & 0.681 & 0.768 & 0.748 \\
\hline $\mathrm{Al}_{2} \mathrm{O}_{3} \mathrm{wt} \%$ & 16.7 & 16.84 & 17.33 & 19.14 & 19.13 & 15.19 & 16.13 & 16.49 & 16.76 & 16.56 & 17.18 & 16.29 \\
\hline $\mathrm{Fe}_{2} \mathrm{O}_{3}(\mathrm{t}) \mathrm{wt} \%$ & 5.67 & 4.59 & 3.64 & 4.06 & 4.08 & 3.32 & 3.53 & 3.98 & 4.59 & 4.09 & 4.8 & 4.51 \\
\hline $\mathrm{MnO} w \mathrm{t} \%$ & 0.101 & 0.067 & 0.077 & 0.097 & 0.087 & 0.045 & 0.028 & 0.051 & 0.074 & 0.073 & 0.076 & 0.057 \\
\hline $\mathrm{MgO} w \mathrm{wt} \%$ & 1.86 & 2.17 & 1.24 & 1.31 & 1.23 & 0.74 & 0.73 & 1.54 & 2.11 & 1.48 & 2.11 & 1.47 \\
\hline $\mathrm{CaO}$ wt $\%$ & 5.84 & 4.47 & 5.79 & 5.41 & 5.91 & 3.32 & 3.74 & 4.5 & 4.88 & 5.47 & 5.3 & 4.73 \\
\hline $\mathrm{Na}_{2} \mathrm{O} w t \%$ & 4.54 & 5.46 & 4.63 & 4.81 & 4.74 & 4.34 & 4.73 & 4.88 & 5.07 & 4.65 & 4.95 & 4.83 \\
\hline $\mathrm{K}_{2} \mathrm{O} w \mathrm{wt} \%$ & 1.94 & 2.41 & 1.92 & 1.48 & 1.69 & 2.38 & 2.25 & 2.26 & 2.03 & 2.07 & 1.72 & 1.79 \\
\hline $\mathrm{P}_{2} \mathrm{O}_{5} \mathrm{wt} \%$ & 0.29 & 0.23 & 0.2 & 0.28 & 0.29 & 0.19 & 0.22 & 0.26 & 0.28 & 0.27 & 0.34 & 0.35 \\
\hline LOI wt $\%$ & 2.31 & 1.1 & 2.18 & 1.12 & 0.87 & 0.52 & 0.62 & 0.67 & 0.48 & 2.21 & 1.23 & 0.51 \\
\hline Total & 99.95 & 100.6 & 99.00 & 100.00 & 99.82 & 100.4 & 100.2 & 99.25 & 100.6 & 99.59 & 100.5 & 99.93 \\
\hline $\mathrm{FeO}(\mathrm{t})^{*} \mathrm{wt} \%$ & 5.1 & 4.13 & 3.28 & 3.65 & 3.67 & 2.99 & 3.18 & 3.58 & 4.13 & 3.68 & 4.32 & 4.06 \\
\hline La ppm & 21.7 & 20.8 & 12.3 & 17.4 & 14.7 & 18.1 & 17.8 & 16.5 & 19.6 & 16.5 & 22.7 & 21.1 \\
\hline Ce ppm & 46.4 & 44 & 27.1 & 34.7 & 29.8 & 35.5 & 35.6 & 35.1 & 40.4 & 34.2 & 45.3 & 45.5 \\
\hline Pr ppm & 5.32 & 4.9 & 3.22 & 4.32 & 3.81 & 4.3 & 4.13 & 4.4 & 5.24 & 4.4 & 5.76 & 5.62 \\
\hline $\mathrm{Nd}$ ppm & 18.8 & 17.5 & 13.4 & 17.7 & 15.6 & 17 & 16.9 & 18.4 & 22.4 & 18.1 & 23.2 & 22.9 \\
\hline Sm ppm & 4.12 & 3.72 & 3.0 & 3.3 & 2.9 & 3.3 & 3.1 & 3.6 & 4.3 & 3.6 & 4.3 & 4.2 \\
\hline Eu ppm & 1.36 & 1.17 & 1.06 & 1.43 & 1.37 & 1.04 & 1.09 & 1.23 & 1.46 & 1.24 & 1.41 & 1.47 \\
\hline Gd ppm & 3.3 & 2.71 & 2.3 & 2.5 & 2.4 & 2.6 & 2.4 & 2.9 & 3.4 & 2.8 & 3.4 & 3 \\
\hline $\mathrm{Tb}$ ppm & 0.48 & 0.36 & 0.3 & 0.3 & 0.3 & 0.4 & 0.3 & 0.3 & 0.4 & 0.3 & 0.4 & 0.4 \\
\hline Dy ppm & 2.66 & 1.89 & 1.5 & 1.7 & 1.5 & 1.8 & 1.4 & 1.5 & 1.9 & 1.6 & 2.1 & 2.1 \\
\hline Ho ppm & 0.53 & 0.36 & 0.3 & 0.3 & 0.3 & 0.3 & 0.3 & 0.3 & 0.3 & 0.3 & 0.4 & 0.4 \\
\hline Er ppm & 1.59 & 1 & 0.7 & 0.8 & 0.8 & 0.9 & 0.7 & 0.7 & 0.9 & 0.7 & 1 & 1 \\
\hline Tm ppm & 0.226 & 0.141 & 0.10 & 0.12 & 0.11 & 0.12 & 0.11 & 0.1 & 0.13 & 0.1 & 0.14 & 0.15 \\
\hline $\mathrm{Yb}$ ppm & 1.39 & 0.89 & 0.7 & 0.7 & 0.7 & 0.8 & 0.7 & 0.6 & 0.8 & 0.6 & 0.8 & 0.9 \\
\hline
\end{tabular}




\begin{tabular}{|c|c|c|c|c|c|c|c|c|c|c|c|c|}
\hline \multirow{2}{*}{$\begin{array}{c}\text { Area } \\
\text { Location }\end{array}$} & \multicolumn{2}{|c|}{ Tocota } & \multicolumn{10}{|c|}{ Cerro Negro } \\
\hline & $\begin{array}{l}\text { Divisadero } \\
\text { Sur }\end{array}$ & $\begin{array}{c}\text { Co. Divi- } \\
\text { sadero }\end{array}$ & $\begin{array}{c}\text { Co. Puntas } \\
\text { Negras }\end{array}$ & Co. Negro & Co. Negro & Co. Negro & Co. Negro & Co. Negro & Co. Negro & Co. Negro & Co. Negro & Co. Negro \\
\hline Sample & TOC31 & TOC10 & CN201 & $\mathrm{CN} 2$ & CN4 & CN6 & CN15 & CN17 & CN18 & $\mathrm{CN} 23$ & CN27 & CNH31 \\
\hline Petrographic type & Andesite & Andesite & Andesite & Andesite & Andesite & Dacite & Dacite & Dacite & Dacite & Andesite & Andesite & Dacite \\
\hline $\mathrm{Lu} \mathrm{ppm}$ & 0.217 & 0.14 & 0.09 & 0.11 & 0.1 & 0.12 & 0.1 & 0.09 & 0.11 & 0.09 & 0.11 & 0.12 \\
\hline Y ppm & 15.2 & 10.2 & 7 & 8 & 7 & 9 & 7 & 7 & 9 & 9 & 10 & 10 \\
\hline $\mathrm{Sr}$ ppm & 892 & 1,009 & 730 & 813 & 864 & 655 & 728 & 888 & 929 & 879 & 953 & 928 \\
\hline Ba ppm & 784 & 805 & 624 & 544 & 571 & 691 & 700 & 686 & 660 & 676 & 758 & 733 \\
\hline Cs ppm & 0.9 & 1 & 0.7 & 0.6 & 0.5 & 0.7 & 1 & 0.7 & 0.7 & 0.7 & 1 & 0.6 \\
\hline $\mathrm{U}$ ppm & 0.86 & 0.98 & 0.7 & 0.5 & 1.1 & 0.9 & 0.8 & 0.7 & 0.6 & 0.9 & 0.5 & 0.8 \\
\hline Th ppm & 1.95 & 2.51 & 1.1 & 1.3 & 1.1 & 2.4 & 1.7 & 1.6 & 1.6 & 1.6 & 1.7 & 1.5 \\
\hline Hf ppm & 5 & 4 & 3.2 & 2.7 & 2.7 & 3.5 & 3.5 & 3.3 & 3.6 & 3.3 & 3.5 & 3.5 \\
\hline Ta ppm & 0.54 & 0.46 & 0.8 & 0.7 & 0.7 & 0.8 & 0.8 & 0.6 & 0.7 & 0.6 & 0.5 & 0.4 \\
\hline $\mathrm{Rb}$ ppm & 32 & 36 & 37 & 27 & 29 & 43 & 39 & 37 & 35 & 34 & 32 & 28 \\
\hline $\mathrm{Nb}$ ppm & 9.1 & 7.8 & 11 & 10 & 9 & 11 & 10 & 8 & 9 & 9 & 8 & 6 \\
\hline Zr ppm & 197 & 143 & 105 & 102 & 102 & 119 & 126 & 123 & 130 & 134 & 145 & 143 \\
\hline $\mathrm{Sr} / \mathrm{Y}$ & 58.7 & 98.9 & 98.1 & 101.6 & 123.4 & 72.8 & 104.0 & 126.9 & 103.2 & 97.7 & 95.3 & 92.8 \\
\hline $\mathrm{Ba} / \mathrm{La}$ & 36.1 & 38.7 & 50.6 & 31.3 & 38.8 & 38.2 & 39.3 & 41.6 & 33.7 & 41.0 & 33.4 & 34.7 \\
\hline $\mathrm{La} / \mathrm{Sm}$ & 5.3 & 5.6 & 4.1 & 5.3 & 5.1 & 5.5 & 5.7 & 4.6 & 4.6 & 4.6 & 5.3 & 5.0 \\
\hline $\mathrm{La} / \mathrm{Yb}$ & 15.6 & 23.4 & 18.3 & 24.9 & 21.0 & 22.6 & 25.4 & 27.5 & 24.5 & 27.5 & 28.4 & 23.4 \\
\hline $\mathrm{Sm} / \mathrm{Yb}$ & 3.0 & 4.2 & 4.4 & 4.7 & 4.1 & 4.1 & 4.4 & 6.0 & 5.4 & 6.0 & 5.4 & 4.7 \\
\hline $\mathrm{Ba} / \mathrm{Ta}$ & 1,452 & 1,750 & 776 & 777 & 816 & 864 & 875 & 1,143 & 943 & 1,127 & 1,516 & 1,833 \\
\hline $\mathrm{La} / \mathrm{Ta}$ & 40.2 & 45.2 & 15.3 & 24.9 & 21.0 & 22.6 & 22.3 & 27.5 & 28.0 & 27.5 & 45.4 & 52.8 \\
\hline $\mathrm{Gd} / \mathrm{Yb}$ & 2.37 & 3.0 & 3.4 & 3.6 & 3.4 & 3.3 & 3.4 & 4.8 & 4.3 & 4.7 & 4.3 & 3.3 \\
\hline $\mathrm{Rb} / \mathrm{Nb}$ & 3.51 & 4.6 & 3.3 & 2.7 & 3.2 & 3.9 & 3.9 & 4.6 & 3.9 & 3.8 & 4.0 & 4.7 \\
\hline $\mathrm{Sr} / \mathrm{Nb}$ & 98.0 & 129.4 & 65.0 & 81.3 & 96.0 & 59.5 & 72.8 & 111.0 & 103.2 & 97.7 & 119.1 & 154.7 \\
\hline \multirow[t]{2}{*}{ Coordinates } & $30^{\circ} 44^{\prime} 49^{\prime \prime} \mathrm{S}$ & $30^{\circ} 40^{\prime} 56^{\prime \prime} \mathrm{S}$ & $30^{\circ} 31^{\prime} 20^{\prime \prime} \mathrm{S}$ & $30^{\circ} 30^{\prime} 17^{\prime \prime} \mathrm{S}$ & $30^{\circ} 30^{\prime} 17^{\prime \prime} \mathrm{S}$ & $30^{\circ} 30^{\prime} 26^{\prime \prime} \mathrm{S}$ & $30^{\circ} 32^{\prime} 42^{\prime \prime} \mathrm{S}$ & $30^{\circ} 32^{\prime} 30^{\prime \prime} \mathrm{S}$ & $30^{\circ} 32^{\prime} 30^{\prime \prime} \mathrm{S}$ & $30^{\circ} 32^{\prime} 47^{\prime \prime} \mathrm{S}$ & $30^{\circ} 25^{\prime} 58^{\prime \prime} \mathrm{S}$ & $30^{\circ} 26^{\prime} 01^{\prime \prime S}$ \\
\hline & $69^{\circ} 24^{\prime} 58^{\prime \prime} \mathrm{S}$ & $69^{\circ} 26^{\prime} 11^{\prime \prime} \mathrm{S}$ & $69^{\circ} 07^{\prime} 24^{\prime \prime} \mathrm{S}$ & $69^{\circ} 10^{\prime} 16^{\prime \prime} \mathrm{S}$ & $69^{\circ} 10^{\prime} 16^{\prime \prime} \mathrm{S}$ & $69^{\circ} 09^{\prime} 57^{\prime \prime} \mathrm{S}$ & $69^{\circ} 10^{\prime} 4^{\prime \prime} \mathrm{S}$ & $69^{\circ} 10^{\prime} 00^{\prime \prime} \mathrm{S}$ & $69^{\circ} 10^{\prime} 05^{\prime \prime} \mathrm{S}$ & $69^{\circ} 10^{\prime} 11^{\prime \prime S}$ & $69^{\circ} 11^{\prime} 07^{\prime \prime} \mathrm{S}$ & $69^{\circ} 11^{\prime} 06^{\prime \prime S}$ \\
\hline
\end{tabular}

